\title{
Article \\ Growth Properties and Sensitivities to Various Bactericidal Methods of Cold-Tolerant Microorganisms Isolated from Packed Tofu
}

\author{
Masayoshi Matsui ${ }^{1}$, Takanori Tanino ${ }^{1,2}$, Misato Ito ${ }^{1}$, Chihiro Nomura $^{1}$, Alexis Guionet ${ }^{3}$, \\ Katsuyuki Takahashi ${ }^{3,4}$ (D), Koichi Takaki ${ }^{3,4}$ (D) and Takayuki Ohshima ${ }^{1,2, *(D)}$
}

check for

updates

Citation: Matsui, M.; Tanino, T.; Ito,

M.; Nomura, C.; Guionet, A.;

Takahashi, K.; Takaki, K.; Ohshima, T.

Growth Properties and Sensitivities

to Various Bactericidal Methods of

Cold-Tolerant Microorganisms

Isolated from Packed Tofu. Agronomy 2022, 12, 233. https://doi.org/

10.3390 /agronomy12020233

Academic Editor: Sung-Cheol Koh

Received: 26 December 2021

Accepted: 17 January 2022

Published: 18 January 2022

Publisher's Note: MDPI stays neutral with regard to jurisdictional claims in published maps and institutional affiliations.

Copyright: (C) 2022 by the authors. Licensee MDPI, Basel, Switzerland. This article is an open access article distributed under the terms and conditions of the Creative Commons Attribution (CC BY) license (https:// creativecommons.org/licenses/by/ $4.0 /)$.
1 Division of Environmental Engineering Science, Graduate School of Science and Technology, Gunma University, 1-5-1 Tenjin-cho, Kiryu, Gunma 376-8515, Japan; m-matsui@gunma-u.ac.jp (M.M.); ttanino@gunma-u.ac.jp (T.T.); t13303008@gunma-u.ac.jp (M.I.); t14303074@gunma-u.ac.jp (C.N.)

2 Center for Food Science and Wellness, Gunma University, 4-2 Aramaki-machi, Maebashi, Gunma 371-8510, Japan

3 Agri-Innovation Center, Iwate University, 3-18-8 Ueda, Morioka, Iwate 020-8550, Japan; guionet@iwate-u.ac.jp (A.G.); ktaka@iwate-u.ac.jp (K.T.); takaki@iwate-u.ac.jp (K.T.)

4 Faculty of Science and Engineering, Iwate University, 4-3-5 Ueda, Morioka, Iwate 020-8551, Japan

* Correspondence: tohshima@gunma-u.ac.jp; Tel.: +81-27-730-1470

Abstract: Disinfection and sterilization against cold-tolerant microorganisms are very important for enhancing food safety and hygiene management under refrigeration conditions. We isolated Exiguobacterium sp. and Pantoea sp. from an immersion solution of packed tofu and evaluated their growth properties and sensitivities to various bactericidal methods. These microorganisms were classified as psychrotrophic bacteria, according to their ability to grow at $4{ }^{\circ} \mathrm{C}$, with an optimum growth temperature of $30^{\circ} \mathrm{C}$. Exiguobacterium sp. and Pantoea sp. were more sensitive to heat and sodium hypochlorite than Escherichia coli (E. coli). Exiguobacterium sp. was sensitive to acetic acid and citric acid, while Pantoea sp. was relatively insensitive and E. coli was insensitive to these organic acids. All microorganisms used in this study were resistant to sodium hydroxide solution ( $\mathrm{pH}$ 8.00). Exiguobacterium sp. showed resistance to ozonated water and UV; therefore, particular attention should be paid to the contamination of this microorganism in food factories. Both Exiguobacterium sp. and Pantoea sp. were inactivated by pulsed electric field (PEF) treatment that did not cause lethal damage to $E$. coli. The results obtained in this study suggest that the bactericidal methods targeting the fragile cell membrane with high permeability are effective for the inactivation of cold-tolerant microorganisms.

Keywords: sterilization; tofu; cold tolerance; psychrotrophic bacteria; pulsed electric field

\section{Introduction}

From the standpoint of food safety and hygiene management, the methods of microbial control, for example, bacteriostatic treatment, decontamination, disinfection, and sterilization are very important. Since the most common food spoilage microorganisms are mesophiles [1], refrigeration and freezing are commonly employed as effective food preservation methods. However, the deterioration and spoilage of chilled food occurs frequently by cold-tolerant microorganisms, such as psychrophilic and psychrotrophic bacteria [2]. With the growth of the global cold chain market size, there is a great demand for enhancing the microbiological safety and quality of various foods under refrigeration conditions, especially perishable ones. Hence, the isolation, identification, and inactivation of cold-tolerant food spoilage microorganisms have been recognized as significant research issues.

Tofu is a gel-like food, prepared by coagulating soy milk. Owing to the health benefits of tofu as an excellent protein source with high quality nutrients, it has become very popular 
all over the world. Tofu is particularly susceptible to microbial contamination because of its high moisture $(>80 \%)$, high protein content [3,4] (6-8.4\%) [5], and near-neutral $\mathrm{pH}$, in the range of 5.8 to 6.2 [4]. Thus, the shelf life of tofu is very short, even under preservation conditions like refrigeration. For example, the shelf lives of fresh and packed tofu in Japan are 1 to 5 days and about 1 week, respectively [6]. The isolation and identification of cold-tolerant food spoilage microorganisms from tofu have been performed from the standpoint of microbiological quality management $[3,7,8]$, estimation of shelf life [9], and quantitative microbial risk assessment [10]. In order to improve the microbiological safety and quality of tofu, it is necessary to determine the effective bactericidal methods for these microorganisms. However, the sensitivities of these microorganisms toward various bactericidal methods have not been sufficiently investigated.

In this study, we aimed to isolate cold-tolerant food spoilage microorganisms from packed tofu and to evaluate their growth properties and sensitivities to various bactericidal methods. To obtain ozone-resistant microorganisms, the filling water of the packed tofu was substituted with 5 ppm ozonated water. Exiguobacterium sp. and Pantoea sp. were isolated from an immersion solution of packed tofu stored at $4{ }^{\circ} \mathrm{C}$ for 6 days. The growth properties of each microorganism in soy milk were evaluated from growth curves obtained at different temperatures, ranging from 4 to $37^{\circ} \mathrm{C}$. Furthermore, sensitivities of these microorganisms toward various bactericidal methods, such as heat, sodium hypochlorite $(\mathrm{NaOCl})$, organic acids, alkaline, ozone, ultraviolet (UV), and pulsed electric field (PEF) were investigated. The results were compared with those of Escherichia coli (E. coli), which is recognized as a hygiene indicator organism in foods [11]. The factors affecting the sensitivity of each microorganism to various bactericidal methods were also discussed, based on the difference in the structure of cells and functions of intracellular components.

\section{Materials and Methods}

\subsection{Isolation and Identification of Microorganisms}

The packed tofu used in this study was purchased at a grocery store in Japan. Ozonated water was made from tap water using an ozonizer (Masuda Research Inc., Tokyo, Japan). To remove chlorine by evaporation, tap water was left to stand at room temperature overnight. The concentration of ozonated water was determined by the measurement of the absorbance at $260 \mathrm{~nm}$ by a spectrophotometer (UV-mini 1240: Shimadzu Corp., Kyoto, Japan). The filling water of the packed tofu was substituted with 5 ppm ozonated water, and the pack was sealed again, with the sample then stored at $4{ }^{\circ} \mathrm{C}$. An aliquot of the filling solution collected after 6 days was serially diluted with distilled water and $0.1 \mathrm{~mL}$ of each dilution was plated on a nutrient agar plate (Bacto peptone $10 \mathrm{~g} / \mathrm{L}$, Bacto beef extract $5 \mathrm{~g} / \mathrm{L}, \mathrm{NaCl}$ $5 \mathrm{~g} / \mathrm{L}$, agar $15 \mathrm{~g} / \mathrm{L}$ ). After incubation at $37^{\circ} \mathrm{C}$ for $24 \mathrm{~h}$, isolated orange and yellow colonies were obtained. Samples of isolated microorganisms were sent to BEX Co., Ltd., Tokyo, Japan and identified by $16 \mathrm{~S}$ rRNA gene sequence analysis. Polymerase chain reaction (PCR) amplification of the 16S rRNA genes of isolates was carried out using the primers 10F (5'-GTTTGATCCTGGCTCA-3') and 800R (5'-TACCAGGGTATCTAATCC-3'). The PCR products were sequenced using an automated DNA sequencer. Taxonomic identification was performed using Basic Local Alignment Search Tool (BLAST) database [12].

\subsection{Culture of Microorganisms at Different Temperatures}

The isolated microorganisms (Exiguobacterium sp. and Pantoea sp.) were cultivated in $10 \mathrm{~mL}$ of nutrient broth (Bacto peptone $10 \mathrm{~g} / \mathrm{L}$, Bact beef extract $5 \mathrm{~g} / \mathrm{L}, \mathrm{NaCl} 5 \mathrm{~g} / \mathrm{L}$ ) at $37^{\circ} \mathrm{C}$ for $18 \mathrm{~h}$ with shaking. After cultivation, $0.1 \mathrm{~mL}$ of each cell culture was inoculated into $10 \mathrm{~mL}$ of soy milk (Kikkoman Co., Ltd., Chiba, Japan) and then cultivated at different temperatures ranging from 4 to $37^{\circ} \mathrm{C}$ for various periods up to 6 days with shaking. A pharmaceutical refrigerator with freezer (SANYO Medicool MPR-411F, SANYO Electric Co., Ltd., Osaka, Japan) and a laboratory incubator (SANYO Incubator MIR-151, SANYO Electric Co., Ltd., Osaka, Japan) were used to maintain culture temperatures at $4{ }^{\circ} \mathrm{C}$ and at $10-37^{\circ} \mathrm{C}$, respectively. Cell cultures of $0.4 \mathrm{~mL}$ were collected at constant time intervals and 
serially diluted with distilled water. Next, $0.1 \mathrm{~mL}$ of the dilutions were plated on nutrient agar plates. The plates were incubated at the same temperature at which the collected cell culture was cultivated. After incubation for various periods, colonies were counted to determine the numbers of colony forming units (CFU). Growth curves were obtained by plotting CFU/mL against the cultivation time. The doubling time and specific growth rate were calculated to evaluate the growth characteristics of each microorganism.

\subsection{Preparation of Cell Suspensions}

Exiguobacterium sp. and Pantoea sp. were cultivated in $10 \mathrm{~mL}$ of nutrient broth at $4{ }^{\circ} \mathrm{C}$ for 5 days with shaking. After cultivation, the cells of each microorganism were collected using a centrifuge $\left(10,000 \mathrm{rpm}, 5 \mathrm{~min}, 4^{\circ} \mathrm{C}\right)$ and washed twice with distilled water. The cells suspended in distilled water were collected using a centrifuge $\left(10,000 \mathrm{rpm}, 5 \mathrm{~min}, 4^{\circ} \mathrm{C}\right)$ and the pelleted cells were resuspended in distilled water. The initial cell concentration of each microorganism was about $10^{7}-10^{9} \mathrm{CFU} / \mathrm{mL}$.

E. coli K-12 strain was cultivated in $10 \mathrm{~mL}$ of Luria-Bertani (LB) medium (Bacto peptone $10 \mathrm{~g} / \mathrm{L}$, Bacto yeast extract $5 \mathrm{~g} / \mathrm{L}, \mathrm{NaCl} 5 \mathrm{~g} / \mathrm{L})$ at $37^{\circ} \mathrm{C}$ for $18 \mathrm{~h}$ with shaking. After cultivation, E. coli cells were collected using a centrifuge $\left(10,000 \mathrm{rpm}, 5 \mathrm{~min}, 4^{\circ} \mathrm{C}\right)$ and washed twice with distilled water. The cells suspended in distilled water were collected using a centrifuge $\left(10,000 \mathrm{rpm}, 5 \mathrm{~min}, 4^{\circ} \mathrm{C}\right)$ and the pelleted cells were resuspended in distilled water. The initial cell concentration was about $10^{7}-10^{9} \mathrm{CFU} / \mathrm{mL}$.

\subsection{Bactericidal Methods}

\subsubsection{Heat Treatment}

Cell suspensions of $5 \mathrm{~mL}$ were dispensed into test tubes and held in a thermostatic water bath (Shimadzu Water Bath BW-4: Shimadzu Corp., Kyoto, Japan) at 45, 50, 55, and $60{ }^{\circ} \mathrm{C}$ for $20 \mathrm{~min}$. Then, the suspensions of $0.4 \mathrm{~mL}$ were collected at $5 \mathrm{~min}$ intervals and immediately quenched in an ice bath. The collected samples were serially diluted with distilled water and $0.1 \mathrm{~mL}$ of the dilutions of Exiguobacterium sp. and Pantoea sp. cells, and E. coli cells were plated on nutrient agar plates and LB agar plates (Bacto peptone $10 \mathrm{~g} / \mathrm{L}$, Bacto yeast extract $5 \mathrm{~g} / \mathrm{L}, \mathrm{NaCl} 5 \mathrm{~g} / \mathrm{L}$, agar $15 \mathrm{~g} / \mathrm{L}$ ), respectively. After incubation at $37^{\circ} \mathrm{C}$ for $24 \mathrm{~h}$, colonies were counted to determine the number of CFUs. Each experiment was performed three times. The data in the figures are means of the experimental results and error bars indicate maximum and minimum values.

\subsubsection{Ozonated Water Treatment}

Ozonated water was made from tap water using the ozonizer. To remove chlorine by evaporation, tap water was left to stand at room temperature overnight. The concentration of ozonated water was determined by the measurement of the absorbance at $260 \mathrm{~nm}$ by the spectrophotometer. Cell suspensions of $3 \mathrm{~mL}$ were dispensed into test tubes and equal volumes of ozonated water were added to obtain final ozone concentrations of $0.5,1$, and $1.5 \mathrm{ppm}$. The mixtures were left to stand at $20{ }^{\circ} \mathrm{C}$ for $9 \mathrm{~min}$, and sample solutions of $0.4 \mathrm{~mL}$ were collected at $3 \mathrm{~min}$ intervals. The collected samples were serially diluted with distilled water, and $0.1 \mathrm{~mL}$ of the dilutions of Exiguobacterium sp. and Pantoea sp. cells and E. coli cells were plated on nutrient agar plates and LB agar plates, respectively. After incubation at $37^{\circ} \mathrm{C}$ for $24 \mathrm{~h}$, colonies were counted to determine the number of CFUs. Each experiment was performed three times. The data in the figures are means of the experimental results and error bars indicate maximum and minimum values.

\subsubsection{UV Irradiation}

Cell suspensions of $30 \mathrm{~mL}$ were dispensed into glass Petri dishes (90 $\mathrm{mm}$ in diameter) and placed below the germicidal lamp (Mitsubishi GL 15: Mitsubishi Electric Corp., Tokyo, Japan) on a clean bench. The distance between the germicidal lamp and the liquid surface was $507 \mathrm{~mm}$, and the thickness of cell suspension was about $6 \mathrm{~mm}$. Cell suspensions were stirred at $900 \mathrm{rpm}$ using a magnetic stirrer (CT-1AN Pasolina mini stirrer: AS ONE 
Corp., Osaka, Japan) during the UV irradiation at room temperature and cell suspensions of $0.4 \mathrm{~mL}$ were collected at $1 \mathrm{~min}$ intervals for up to $3 \mathrm{~min}$. The collected samples were serially diluted with distilled water and $0.1 \mathrm{~mL}$ of the dilutions of Exiguobacterium sp. and Pantoea sp. cells and E. coli cells were plated on nutrient agar plates and LB agar plates, respectively. After incubation at $37^{\circ} \mathrm{C}$ for $24 \mathrm{~h}$, colonies were counted to determine the number of CFUs. Each experiment was performed three times. The data in the figures are means of the experimental results and error bars indicate maximum and minimum values.

\subsubsection{Sodium Hypochlorite Treatment}

Sodium hypochlorite solution (197-02206, FUJIFILM Wako Pure Chemical Corp., Osaka, Japan) and sodium thiosulfate pentahydrate (197-03585, FUJIFILM Wako Pure Chemical Corp., Osaka, Japan) were used as received. Cell suspensions of $1 \mathrm{~mL}$ were dispensed into test tubes, and equal volumes of diluted sodium hypochlorite solutions were added to obtain final sodium hypochlorite concentrations of $0.25,0.5,1,2$, and 5 ppm, respectively. The mixtures were allowed to stand for $5 \mathrm{~min}$ at room temperature, and $0.1 \mathrm{~mL}$ of sample solutions were collected at $30 \mathrm{~s}$ intervals for the first $1 \mathrm{~min}$ and at $2 \mathrm{~min}$ intervals for the next $4 \mathrm{~min}$. The collected samples were immediately neutralized with sodium thiosulfate solutions and serially diluted with distilled water. Then, $0.1 \mathrm{~mL}$ of the dilutions of Exiguobacterium sp. and Pantoea sp. cells and E. coli cells were plated on nutrient agar plates and LB agar plates, respectively. After incubation at $37^{\circ} \mathrm{C}$ for $24 \mathrm{~h}$, colonies were counted to determine the number of CFUs. Each experiment was performed three times. The data in the figures are means of the experimental results and error bars indicate maximum and minimum values.

\subsubsection{Organic Acids and Alkaline Treatments}

Acetic acid (017-00251, FUJIFILM Wako Pure Chemical Corp., Osaka, Japan), citric acid (030-05525, FUJIFILM Wako Pure Chemical Corp., Osaka, Japan), hydrochloric acid (080-01066, FUJIFILM Wako Pure Chemical Corp., Osaka, Japan), and sodium hydroxide (198-13765, Wako Pure Chemical Corp., Osaka, Japan) were used as received. Cell suspensions of $1 \mathrm{~mL}$ were dispensed into test tubes, and equal volumes of acetic acid solutions ( $\mathrm{pH} 2.68)$, citric acid solutions ( $\mathrm{pH} 2.00)$, and sodium hydroxide solutions ( $\mathrm{pH} 8.00)$ were added. The mixtures were left to stand for $5 \mathrm{~min}$ at room temperature. Sample solutions of $0.1 \mathrm{~mL}$ were collected at $30 \mathrm{~s}$ intervals for the first $1 \mathrm{~min}$ and at $2 \mathrm{~min}$ intervals for the next $4 \mathrm{~min}$. The collected acidic sample solutions and basic sample solutions were immediately neutralized with sodium hydroxide solutions and hydrochloric acid solutions, respectively, and serially diluted with distilled water. Then, $0.1 \mathrm{~mL}$ of the dilutions of Exiguobacterium sp. and Pantoea sp. cells and E. coli cells were plated on nutrient agar plates and LB agar plates, respectively. After incubation at $37^{\circ} \mathrm{C}$ for $24 \mathrm{~h}$, colonies were counted to determine the number of CFUs. Each experiment was performed three times. The data in the figures are means of the experimental results and error bars indicate maximum and minimum values.

\subsubsection{PEF Treatment Chamber and PEF Treatment Procedure}

The PEF treatment chamber was composed of stainless steel plates, acrylic plates, silicone sheets, resin bolts and nuts. Stainless steel plates (1 $\mathrm{mm}$ thickness) used as the high voltage electrode and the earth electrode were placed on both sides of an acrylic plate (100 $\mathrm{mm} \times 100 \mathrm{~mm}, 10 \mathrm{~mm}$ thickness) with a hole (30 $\mathrm{mm}$ in diameter) and an inlet at the top. These components, silicone sheets ( $1 \mathrm{~mm}$ thickness), and acrylic plate ( $3 \mathrm{~mm}$ thickness) were fixed by resin bolts and nuts, and the resulting gap between the electrodes was $10 \mathrm{~mm}$.

A pulsed high voltage of $15 \mathrm{kV}$ was generated with a gap-type pulse generator (Masuda Research Inc., Tokyo, Japan) with a frequency of $50 \mathrm{~Hz}$. The cell suspension of $8 \mathrm{~mL}$ was poured into the camber, then pulsed high voltages were applied for $1 \mathrm{~min}$. The suspensions of $0.4 \mathrm{~mL}$ were collected at $30 \mathrm{~s}$ intervals. The collected samples were serially diluted with distilled water and $0.1 \mathrm{~mL}$ of the dilutions of Exiguobacterium sp. and Pantoea sp. cells and E. coli cells were plated on nutrient agar plates and LB agar plates, 
respectively. After incubation at $37^{\circ} \mathrm{C}$ for $24 \mathrm{~h}$, colonies were counted to determine the number of CFUs. Each experiment was performed three times. The data in the figures are means of the experimental results and error bars indicate maximum and minimum values.

\section{Results and Discussion}

\subsection{Isolation, Identification, and Growth Properties of Microorganisms}

Two types of microorganisms, forming orange and yellow colonies on nutrient agar plates, were isolated from an ozonated immersion solution of packed tofu, stored at $4{ }^{\circ} \mathrm{C}$ for 6 days (Figure 1). This time period corresponds to 4 days after the shelf-life date of the selected tofu sample. Thus, these microorganisms may be involved in the microbial deterioration and spoilage of tofu. Since the tofu sample was preserved under refrigerated conditions in a grocery store and in our laboratory, they could be considered to be coldtolerant microorganisms. The microbial isolates, with orange and yellow colonies, were identified as Exiguobacterium sp. and Pantoea sp., respectively, based on the 16S rRNA gene sequence analysis.
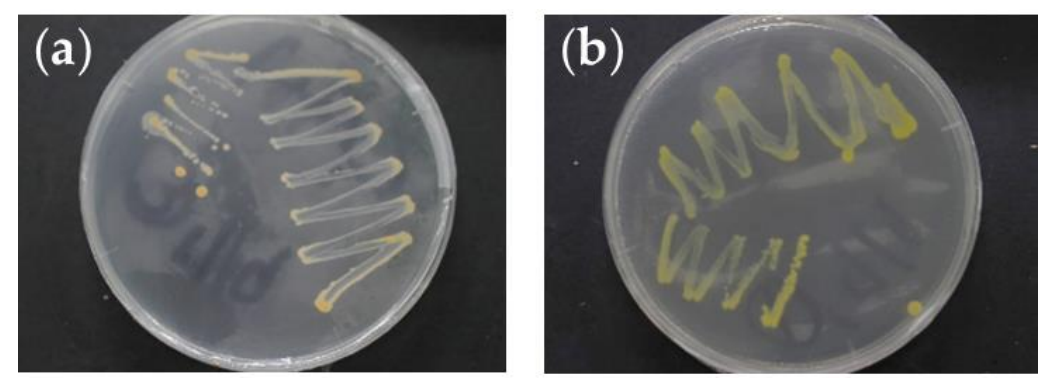

Figure 1. The microbial isolates with orange (a) and yellow colonies (b) from an ozonated immersion solution of packed tofu stored at $4{ }^{\circ} \mathrm{C}$ for 6 days.

Bacteria of the genus Exiguobacterium are Gram-positive, non-sporing, facultative anaerobes [13] with varying morphologies, depending on the strain and growth conditions [14]. Exiguobacterium spp. have been isolated or molecularly detected not only from natural habitats, including a pond [15], a lake [16], and a tidal flat [17], but also extreme environments, such as permafrost [14,18-20], a hot spring [21], the alkaline effluent of a potato-processing factory $[13,22]$, the drain of a fish processing plant with high hydrogen peroxide $\left(\mathrm{H}_{2} \mathrm{O}_{2}\right)$ concentrations [23], high altitude lakes located at $4400 \mathrm{~m}$ [24], a radioactive region [25], and the deep sea at $3044 \mathrm{~m}$ depth [26]. Strains from these extreme environments exhibit resistance to low temperature [14,18-20], high temperature [21], high pH [13,22], high concentrations of $\mathrm{H}_{2} \mathrm{O}_{2}$ [23], high salinity and $\mathrm{UV}$ [24], radiation [25], and high pressure [26]. The adaptability of these strains to various extreme environments is attracting great biological interest, though these unique properties are also very troublesome from the standpoint of microbial control in food safety and hygiene management. For example, when fresh and processed foods are contaminated with cold-tolerant strains that can grow at $-6{ }^{\circ} \mathrm{C}[14],-3{ }^{\circ} \mathrm{C}[20],-2.5{ }^{\circ} \mathrm{C}[18,19], 4{ }^{\circ} \mathrm{C}[18,20,23]$, and $5{ }^{\circ} \mathrm{C}[27]$, it is difficult to prevent the microbial deterioration and spoilage of the foods, even under refrigeration or freezing conditions. The effect of bacteria of the genus Exiguobacterium on the quality of tofu has not been clearly elucidated, but the contribution of a bacterium belonging to the same genus as the spoilage of water-boiled salted duck at $4{ }^{\circ} \mathrm{C}$ has been reported [28]. Since tofu is a protein-rich food like meat, the risk of its deterioration or spoilage by bacteria of the genus Exiguobacterium should be considered concerning. To the best of our knowledge, this study is the first report of a bacterium of the genus Exiguobacterium being isolated from tofu. Although no Exiguobacterium strains have been isolated or molecularly detected from soybeans, Exiguobacterium indicum (E. indicum) has been isolated from the various utensils and tools used during the tofu manufacturing process [29]. Therefore, the equipment used is considered to be a potential source and risk factor for the microbial contamination of tofu. 
Bacteria of the genus Pantoea are Gram-negative, non-sporing, facultative anaerobes, shaped like a straight rod [30]. Pantoea spp. have been isolated or molecularly detected from a wide variety of sources, such as river water [31], spring water [32], soil [33-35], various plants [30,36-45], humans [46,47], and other animals [48,49]. Some strains possess beneficial properties, such as endophytes with plant growth-promoting abilities $[41,42,45]$ and biocontrol agents, which can counter bacterial and fungal plant diseases [39,44]. In contrast, others exhibit deleterious characteristics, such as plant pathogens [40,43] and ice nucleation-active bacteria, that cause frost damage to plants [50,51]. Several cold-tolerant strains that are capable of growth at $3{ }^{\circ} \mathrm{C}$ [39], $5^{\circ} \mathrm{C}$ [33-35], $8{ }^{\circ} \mathrm{C}$ [52], and $10{ }^{\circ} \mathrm{C}$ [51] have also been reported. When fresh and processed foods are contaminated with these strains, it is difficult to prevent the microbial deterioration and spoilage of the foods, even under refrigeration conditions. In fact, Pantoea agglomerans (P. agglomerans, synonym: Enterobacter agglomerans) was isolated from spoiled tofu at $2-3{ }^{\circ} \mathrm{C}$ [7] and at $7{ }^{\circ} \mathrm{C}$ [8]. Fouad et al. reported that this strain caused a putrid odor in spoiled tofu [7]. Since several strains of the genus Pantoea have been isolated or molecularly detected from leaves [36-38,40] and the rhizosphere [33] of soybeans and humans [46,47], it is assumed that the ingredients and workers are potential sources and risk factors for the microbial contamination of tofu.

Growth properties of Exiguobacterium sp. and Pantoea sp. were evaluated from growth curves obtained at different temperatures, ranging from 4 to $37^{\circ} \mathrm{C}$ (Figure 2a). Assuming the contamination of these microorganisms during the process of tofu manufacturing, soy milk was selected as the culture medium. Since the proliferation of Exiguobacterium sp. and Pantoea sp. was observed at all cultivation temperatures, it was confirmed that these microorganisms can utilize soy milk as a nutrient source. Interestingly, these microorganisms were able to grow at refrigeration temperatures $\left(4\right.$ and $\left.10^{\circ} \mathrm{C}\right)$. Although the growth of each microorganism was slow, at $10^{\circ} \mathrm{C}$ or below, the maximum cell concentration in the stationary phase reached about $10^{9} \mathrm{CFU} / \mathrm{mL}$, this value being almost the same as those obtained at room temperature $\left(15-25^{\circ} \mathrm{C}\right)$ or above. When these microorganisms contaminate packed tofu, they continue to grow, even under refrigeration conditions, and it is estimated that after 4 to 5 days, the cell concentration will reach the same level as that of packed tofu left at room temperature for half a day. These results suggest that these microorganisms may be involved in the microbial deterioration and spoilage of tofu under refrigerated conditions. To understand the growth properties of Exiguobacterium sp. and Pantoea sp. in more detail, the specific growth rate and doubling time of each microorganism was calculated using following equations:

$$
\mu t=\ln \frac{n}{n_{0}}
$$

where $\mu$ is the specific growth rate (1/time), $t$ is the cultivation time, $n_{0}$ is the initial number of cells, $n$ is the number of cells after time $t$.

$$
t_{d}=\frac{\ln 2}{\mu}
$$

where $t_{d}$ is the doubling time, $\mu$ is the specific growth rate $(1 /$ time). The optimal growth temperature for each microorganism was estimated to be around $30{ }^{\circ} \mathrm{C}$, at which the doubling time was at its minimum and the specific growth rate was at its maximum (Figure $2 b, c)$. The value was close to the optimal temperatures of other strains, for example, $34{ }^{\circ} \mathrm{C}$ for E. oxidotolerans T-2-2 ${ }^{\mathrm{T}}$ [23] and $30{ }^{\circ} \mathrm{C}$ for P. agglomerans CPA-2 [39]. According to Morita's definition [53], Exiguobacterium sp. and Pantoea sp. were classified as psychrotrophic bacteria because they can grow at low temperatures $\left(0-5^{\circ} \mathrm{C}\right)$ with an optimum growth temperature above $20^{\circ} \mathrm{C}$. 
(a)
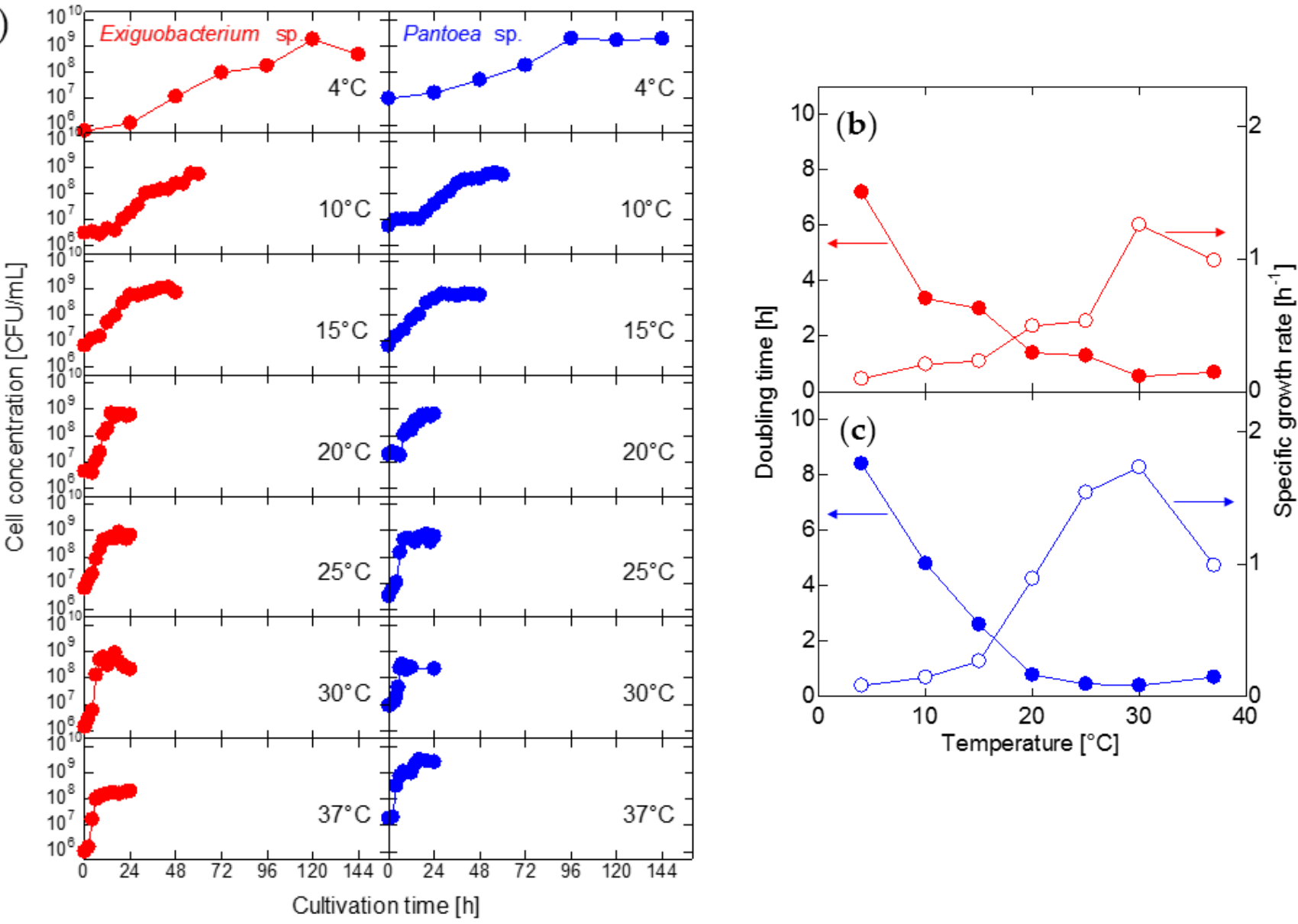

Figure 2. Growth curves of Exiguobacterium sp. and Pantoea sp. at different temperatures (a). Doubling time and specific growth rate of Exiguobacterium sp. (b) and Pantoea sp. (c). Symbols indicate doubling time (closed circles) and specific growth rate (open circles).

\subsection{Sensitivities of Each Microorganism to Various Bactericidal Methods}

\subsubsection{Heat Treatment}

Heat treatment has been widely used in the food industry because of its capacity to inactivate vegetative cells, bacterial spores, yeasts, and molds [54]. In most cases, especially under severe treatment conditions, such as sterilization above $100{ }^{\circ} \mathrm{C}$, the organoleptic and nutritional properties of foods are severely modified [54]. To minimize the required heat treatment, determining the heat resistance of microorganisms is very important. In this study, heat treatment of microorganisms was performed at different temperatures ranging from 45 to $60^{\circ} \mathrm{C}$ (Figure 3). The viable cell density of Exiguobacterium sp. maintained almost the same level as the initial value, at $45^{\circ} \mathrm{C}$ for $20 \mathrm{~min}$. At higher temperatures, it was reduced slowly over time and was not detected at $50{ }^{\circ} \mathrm{C}$ for $15 \mathrm{~min}$, and at $55{ }^{\circ} \mathrm{C}$ or higher for $5 \mathrm{~min}$, respectively (Figure 3a). Similar behavior was observed for Pantoea sp., although the time to reach almost undetectable levels at $50{ }^{\circ} \mathrm{C}$ was shortened to $10 \min$ (Figure 3b). E. coli showed the highest heat resistance among these microorganisms. At $50{ }^{\circ} \mathrm{C}$, only $1 \log$ reduction in CFU $/ \mathrm{mL}$ was observed. No viable cells were detected at $55^{\circ} \mathrm{C}$ for $20 \mathrm{~min}$ (Figure 3c). The activation energies for thermal inactivation of each microorganism were calculated from the slopes of the Arrhenius plots. The activation energy values were 826 , 605, and $480 \mathrm{~kJ} / \mathrm{mol}$ for Exiguobacterium sp., Pantoea sp., and E. coli, respectively. The values for Exiguobacterium sp. and Pantoea sp. are higher than for E. coli, suggesting that their heat tolerance properties are theoretically lower than that of E. coli. In fact, these microorganisms are inactivated at lower temperatures, with shorter treatment times than E. coli (Figure 3). The experimental data shows good agreement with the theoretical result. We predicted that 
soybeans could be the potential source of contamination of several strains belonging to the genus Pantoea for tofu. If the lethal temperatures for these strains are comparable to that for Pantoea sp., our prediction is not acceptable because ground soybeans are cooked by steam above $100{ }^{\circ} \mathrm{C}$ in the tofu production process [7].

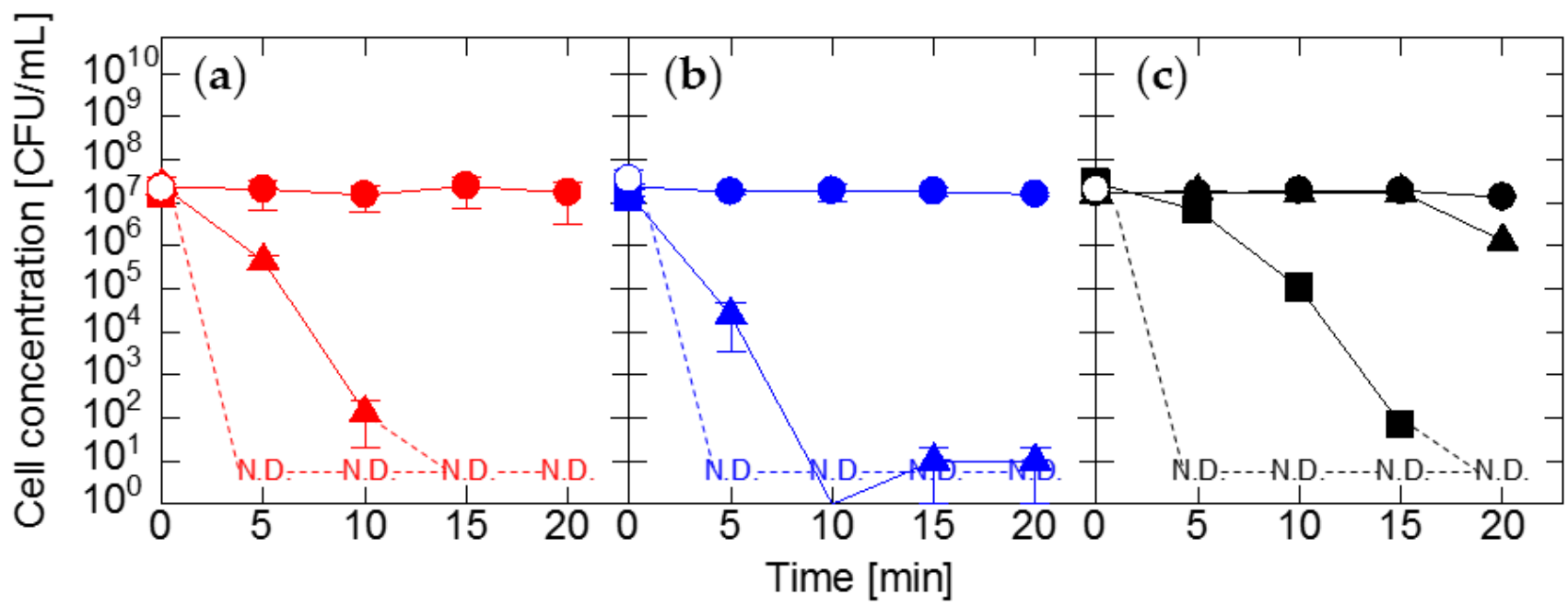

Figure 3. Effect of heat treatment on Exiguobacterium sp. (a), Pantoea sp. (b), and E. coli (c). Symbols indicate temperatures of $45^{\circ} \mathrm{C}$ (closed circles), $50{ }^{\circ} \mathrm{C}$ (closed triangles), $55^{\circ} \mathrm{C}$ (closed squares), and $60{ }^{\circ} \mathrm{C}$ (open circles). N.D. means not detected.

\subsubsection{Sodium Hypochlorite Treatment}

Sodium hypochlorite is the most common disinfectant in the food industry. Typically, fruits, vegetables, and cooking utensils are immersed in 50-200 ppm sodium hypochlorite solution [55,56] for $5 \mathrm{~min}$ [56]. When cell suspensions of Exiguobacterium sp., Pantoea sp., and $E$. coli were treated with sodium hypochlorite solution under the above-mentioned conditions, no viable cells were detected within $30 \mathrm{~s}$ (data not shown). Thus, the bactericidal effect of sodium hypochlorite was evaluated at one tenth of the minimum concentration of the normal operating condition (50 ppm) or lower (Figure 4). The viable cell density of Exiguobacterium sp. decreased by approximately $1 \log , 1 \log$, and $4 \log \mathrm{CFU} / \mathrm{mL}$, at $0.25,0.5$, and $1 \mathrm{ppm}$ for $5 \mathrm{~min}$, respectively (Figure $4 \mathrm{a}$ ). At $2 \mathrm{ppm}$ or higher, it was not detected within $30 \mathrm{~s}$. Although no bactericidal effect against Pantoea sp. was observed at $0.25 \mathrm{ppm}$, around a $3 \log$ and $5 \log$ reduction in $\mathrm{CFU} / \mathrm{mL}$ was achieved at 0.5 and $1 \mathrm{ppm}$ for $5 \mathrm{~min}$, respectively (Figure $4 \mathrm{~b}$ ). No viable cells were detected at $2 \mathrm{ppm}$ for $3 \mathrm{~min}$ and $5 \mathrm{ppm}$ for $30 \mathrm{~s}$. For E. coli, no significant reduction in viable cell density was observed at 0.25 to $2 \mathrm{ppm}$ (Figure 4c). No viable cells were detected at $5 \mathrm{ppm}$ for $3 \mathrm{~min}$. The sensitivities of Exiguobacterium sp. and Pantoea sp. to sodium hypochlorite were higher than that of E. coli. In an aqueous solution, chlorine exists in chlorine gas $\left(\mathrm{Cl}_{2}\right)$, hypochlorous acid $(\mathrm{HOCl})$, and hypochlorite ion $\left({ }^{-} \mathrm{OCl}\right)$, and $\mathrm{Cl}_{2}$ readily escapes from the solution. $\mathrm{HOCl}$ exhibits a greater germicidal property than ${ }^{-} \mathrm{OCl}$ because it can penetrate the cell membranes [57]. Since their relative proportions are dependent on the $\mathrm{pH}$ of the solution, the $\mathrm{pH}$ level and the available chlorine content should be considered to evaluate the bactericidal effect of the sodium hypochlorite solution. The $\mathrm{pH}$ values of $0.25,0.5,1,2$, and $5 \mathrm{ppm}$ sodium hypochlorite solutions were $6.11,6.29,6.89,7.68$, and 8.19, respectively. At $0.25,0.5$, and $1 \mathrm{ppm}, \mathrm{HOCl}$ is the major component because the percentages of this molecule are calculated at about 96,94 , and $80 \%$, respectively. Under these conditions, the permeability of the cell membrane of each microorganism would be related to their sensitivity to sodium hypochlorite. In general, microorganisms which grow at low temperatures contain more unsaturated fatty acids than those which grow at high temperatures $[58,59]$. This phenomenon was explained as part of a mechanism to maintain the fluidity and permeability of the cell membrane [60]. Since Exiguobacterium sp. and Pantoea sp. were cultured at $4{ }^{\circ} \mathrm{C}$, the proportion of unsaturated 
fatty acids in their cell membranes may be increased. As a result, the fragility of the cell membrane was enhanced due to the decrease in the gel to liquid-crystalline phase transition temperatures [61]. The bacterial cells of these should become more permeable to $\mathrm{HOCl}$ than that of E. coli cultured at $37^{\circ} \mathrm{C}$; therefore, they are more sensitive to sodium hypochlorite than E. coli. At 2 and $5 \mathrm{ppm},{ }^{-} \mathrm{OCl}$ becomes the predominant chlorine species because the percentages of $\mathrm{HOCl}$ are calculated at about 30 and $7.8 \%$, respectively. Although the germicidal activity of ${ }^{-} \mathrm{OCl}$ is weak, the concentration of this species might be enough to kill all of the microorganisms used in this study, through an oxidizing action from outside the cell.

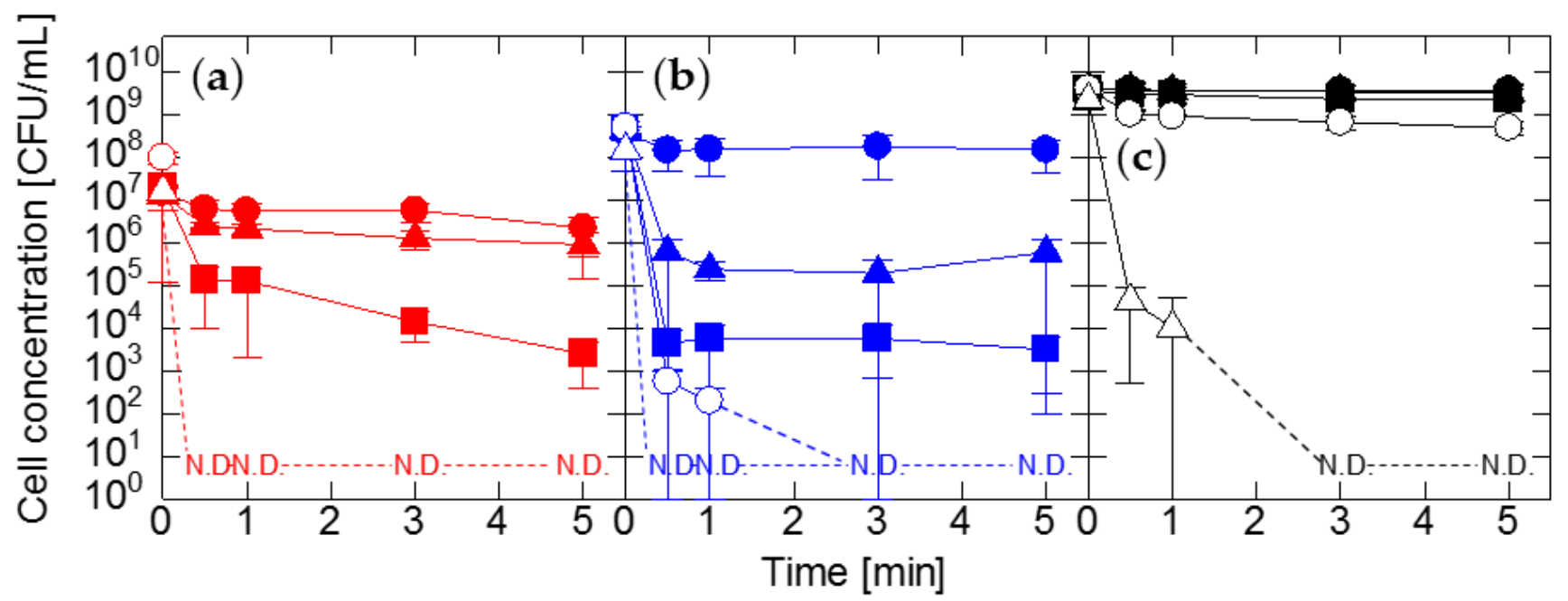

Figure 4. Effect of sodium hypochlorite treatment on Exiguobacterium sp. (a), Pantoea sp. (b), and E. coli (c). Symbols indicate concentrations of $0.25 \mathrm{ppm}$ (closed circles), $0.5 \mathrm{ppm}$ (closed triangles), 1 ppm (closed squares), 2 ppm (open circles), and 5 ppm (open triangles). N.D. means not detected.

\subsubsection{Organic Acids Treatments}

Acetic acid is the main component of vinegar and is used as a potential disinfectant agent, with a broad spectrum of antibacterial activity $[62,63]$. Citric acid is naturally found in citrus fruits and is applied for the inhibition of the growth of various microorganisms, including food poisoning bacteria $[64,65]$. In order to evaluate the bactericidal effect of these organic acids at the actual $\mathrm{pH}$ levels of sour foods, the $\mathrm{pH}$ values of the acetic acid solution ( $\mathrm{pH} 2.68)$ and the citric acid solution $(\mathrm{pH} 2.00)$ were adjusted within the $\mathrm{pH}$ ranges of vinegar $(\mathrm{pH} 2.40-3.40)$ [66] and lemon juice ( $\mathrm{pH}$ 2.00-2.60) [66], respectively. When the cell suspension of Exiguobacterium sp. was treated with the acetic acid solution, about an $8 \log$ reduction in CFU/mL was observed at $30 \mathrm{~s}$ and thereafter (Figure 5a). The viable cell density of Pantoea sp. decreased by about $1 \log C F U / \mathrm{mL}$ for $5 \mathrm{~min}$ (Figure $5 \mathrm{~b}$ ). No bactericidal effect against E. coli was observed because the viable cell density of this microorganism maintained almost the same level as the initial value for $5 \mathrm{~min}$ (Figure 5c). The bactericidal effect of citric acid against these microorganisms showed a similar tendency to that of acetic acid (Figure 6). These results suggest that Exiguobacterium sp. is sensitive, Pantoea sp. is less sensitive and E. coli is insensitive to acetic acid and citric acid. The bactericidal effect of organic acids has been assumed to be due to the penetration of their undissociated forms into the membrane of the bacterial cell, and the subsequent dissociation and release of protons $\left(\mathrm{H}^{+}\right)$in the cytoplasm $[67,68]$. In this study, acetic acid and citric acid would be present largely in the undissociated forms because the $\mathrm{pH}$ of each acidic solution was lower than their acid dissociation constant (pKa) values (acetic acid: 4.76 [69], citric acid: $3.13,4.76$, and 6.41 [70]). Thus, the sensitivities of these microorganisms toward these acids are considered to be dependent on the difference in membrane permeability. Since the Exiguobacterium sp. and Pantoea sp. were cultured at $4{ }^{\circ} \mathrm{C}$, their cell membranes became fragile due to the relatively high content of unsaturated fatty acid in phospholipid molecules. The bacterial cells of these should become more permeable to the undissociated 
forms of organic acids than that of E. coli. The experimental result of Exiguobacterium sp. can be explained by this assumption. The contradictory result of Pantoea sp. suggests that this microorganism may have the natural acid resistance and/or acid tolerance response (ATR) system similar to that of P. agglomerans CPA-2, a microbial antagonist against the major postharvest diseases of citrus and pome fruits [71].

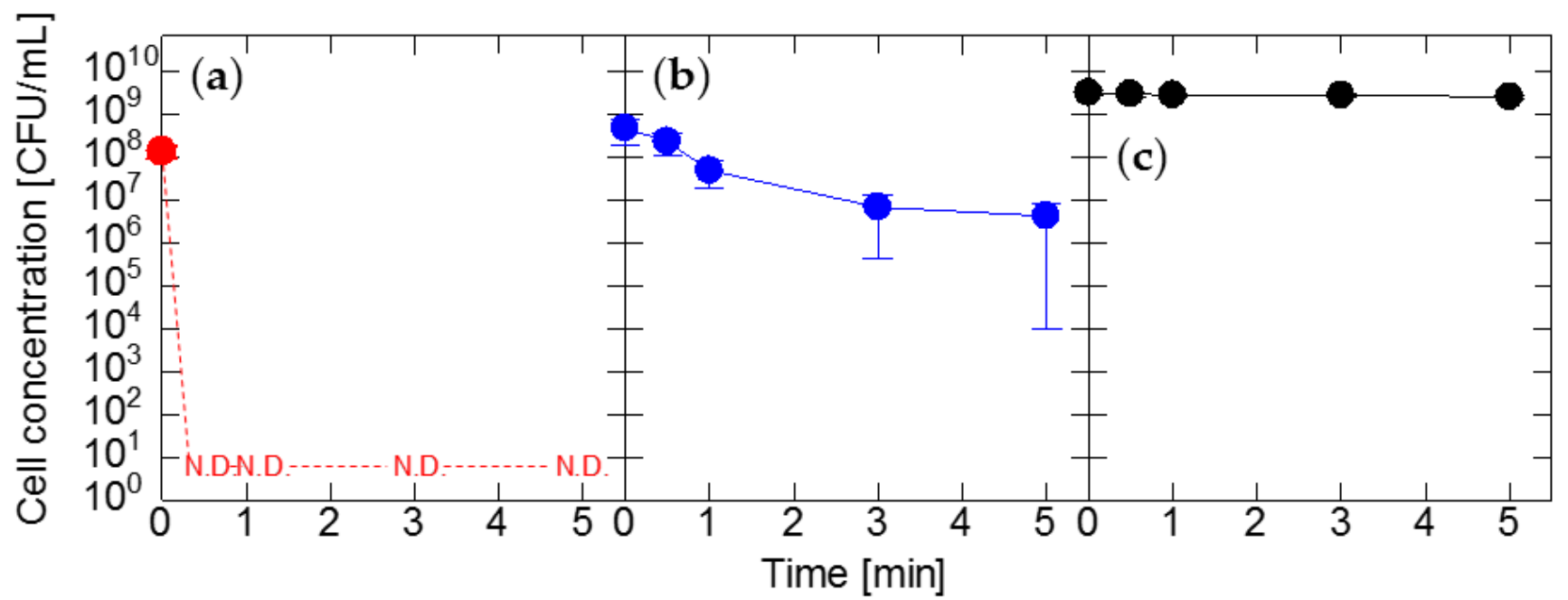

Figure 5. Effect of acetic acid treatment on Exiguobacterium sp. (a), Pantoea sp. (b), and E. coli (c). N.D. means not detected.

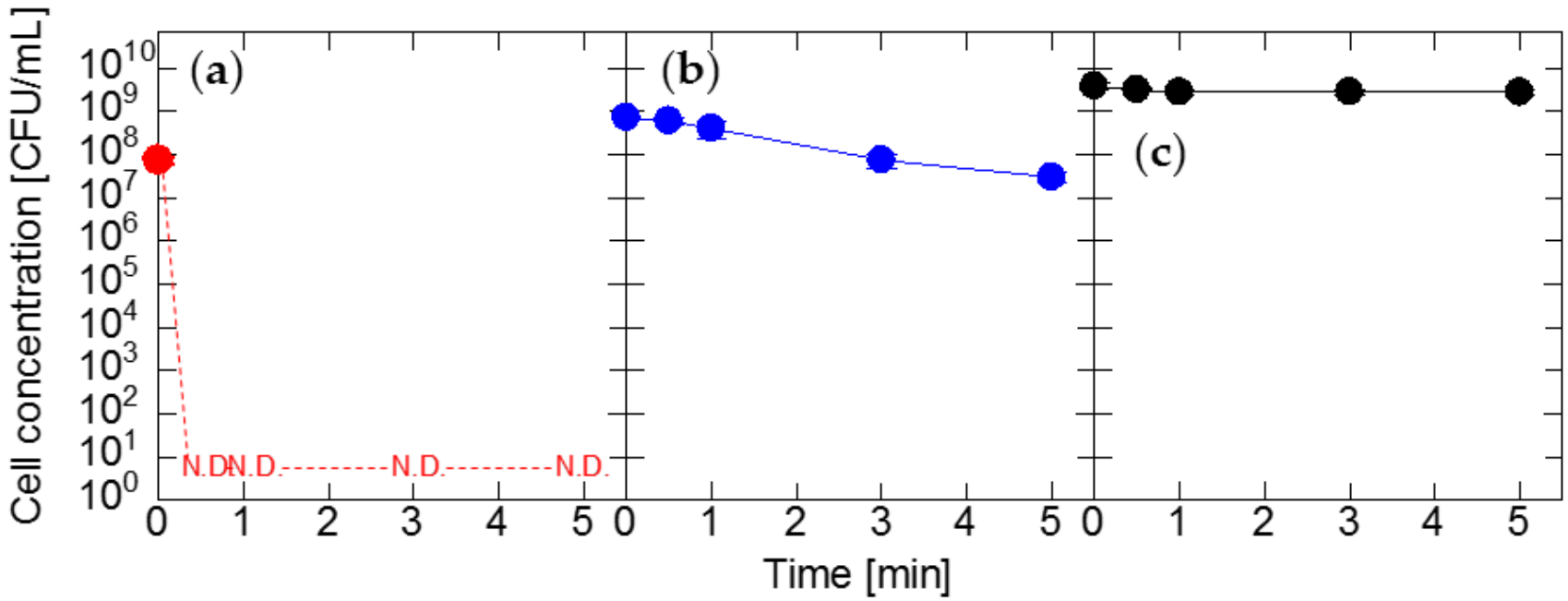

Figure 6. Effect of citric acid treatment on Exiguobacterium sp. (a), Pantoea sp. (b), and E. coli (c). N.D. means not detected.

\subsubsection{Alkaline Treatment}

In order to investigate the sensitivities of Exiguobacterium sp., Pantoea sp., and E. coli to alkaline conditions, these microorganisms were treated with a sodium hydroxide solution ( $\mathrm{pH}$ 8.00). As shown in Figure 7, no bactericidal effect against each microorganism was observed, even after $5 \mathrm{~min}$ of treatment time. This result suggests the potential risk that alkaline sanitizers, such as sodium bicarbonate solution [72] and neutral electrolyzed water (NEW) [73], are ineffective to these microorganisms. However, if the alkaline sanitizers contain other biocidal reagents, the bactericidal effect should be expected because these microorganisms were inactivated by 2 and $5 \mathrm{ppm}$ sodium hypochlorite solutions, with $\mathrm{pH}$ values of 7.68 and 8.19, respectively (Figure 4). NEW seems to be an effective sanitizer against these microorganisms because it contains $\mathrm{HOCl}$ and ${ }^{-} \mathrm{OCl}$ [73]. 


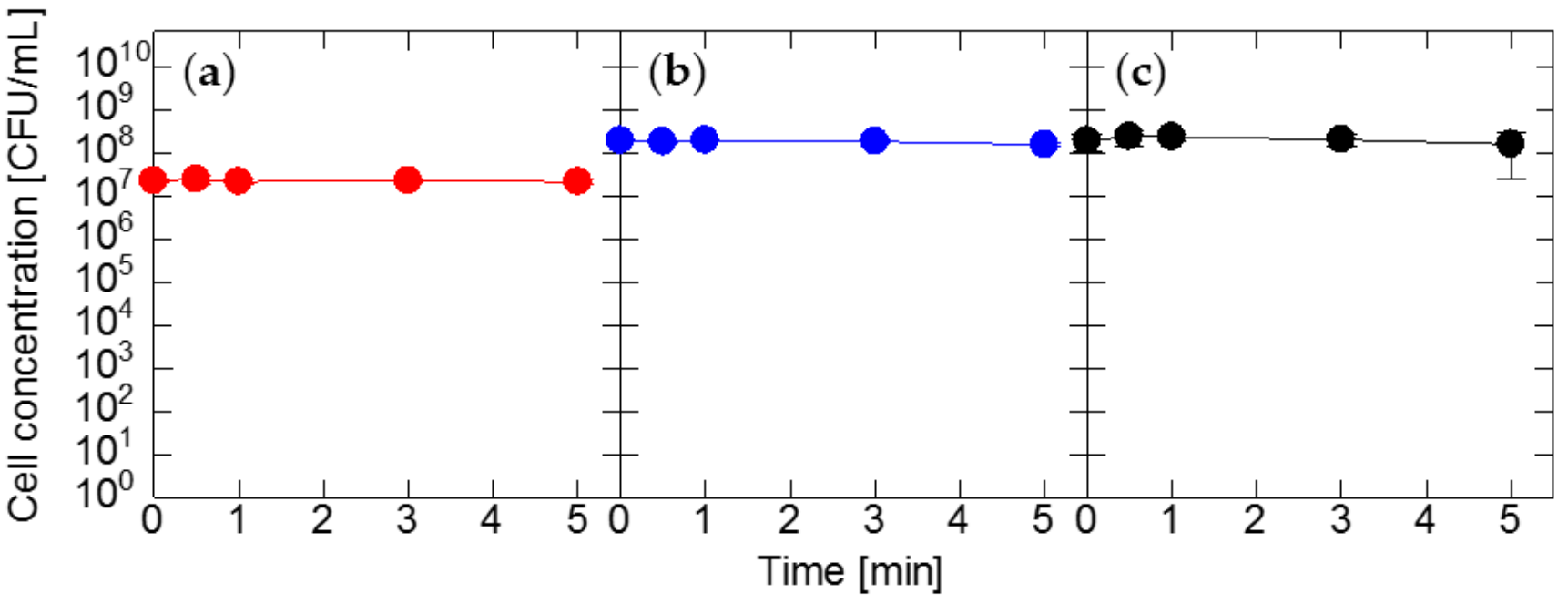

Figure 7. Effect of alkaline treatment on Exiguobacterium sp. (a), Pantoea sp. (b), and E. coli (c).

\subsubsection{Ozonated Water Treatment}

Ozone is a strong oxidant and favorable disinfectant. Because it is easier to handle than ozone gas, ozonated water is applied as the effective sanitizer for various foods [74]. In this study, the bactericidal effect of ozonated water was investigated within the common concentration ranges $(0.5-2.0 \mathrm{ppm})$ used in vegetables and fruits industries [74]. As shown in Figure 8a, no bactericidal effect against Exiguobacterium sp. was observed, even at the highest concentration of $1.5 \mathrm{ppm}$, with the longest treatment time of $9 \mathrm{~min}$. In contrast, Pantoea sp. and E. coli were completely inactivated at the lowest concentration of $0.5 \mathrm{ppm}$, with the shortest treatment time of $3 \mathrm{~min}$ (Figure $8 \mathrm{~b}, \mathrm{c}$ ). It was confirmed that Exiguobacterium sp. is resistant to ozone, and particular attention should be paid to the contamination of this microorganism in food factories, where cleaning and sanitizing are performed using ozonated water, with concentrations of $1.5 \mathrm{ppm}$ or below. Although these microorganisms were isolated from an ozonated immersion solution of packed tofu, Pantoea sp. was not resistant to ozone. There are two possibilities to explain this result. One possibility is a rapid decrease in ozone concentration due to the spontaneous process, and oxidation with tofu and its water-soluble organic compounds, such as proteins, peptides, and polysaccharides. Another possibility is that the planktonic cells of Pantoea sp. were detached from the biofilm, on the surface or the relatively central portion of the tofu, after the decomposition of ozone was completed. The bactericidal effect of ozone is based on the destruction of bacterial cells, which occurs due to the interaction of ozone molecules, reactive oxygen species (ROS) [75,76] and reactive nitrogen species (NOS) [75], with the cell wall [76]. In addition, intracellular components, such as enzymes and nucleic acids are also targeted [76]. Therefore, the sensitivity of each microorganism to ozonated water might be related to the difference in the structure of the cell wall and the cell membrane, as well as the activities of antioxidants and antioxidant enzymes. Considering the selectivity of ozone towards double bonds of unsaturated lipids in the cell membranes [77], Exiguobacterium sp. and Pantoea sp. should become vulnerable to ozone, because the proportion of unsaturated fatty acids in the cell membranes of these microorganisms may be increased at a low culture temperature of $4{ }^{\circ} \mathrm{C}$. However, the experimental result of the former did not obey this assumption (Figure 8a). The involvement of the factors that contribute to ozone resistance should be considered concerning. Since Exiguobacterium sp. is a Gram-positive bacterium, a thick peptidoglycan layer (20-80 nm) [78] may protect bacterial cells from ozone and other reactive species. It is also necessary to think about the defense systems of antioxidants and antioxidant enzymes, with reference to the examples of other strains of the same genus. Exiguobacterium sp. may produce carotenoids because the characteristic of this microorganism to form orange colonies (Figure 1a) was consistent with several carotenoid-producing strains [24,25]. Other strains can produce highly active antioxidant 
enzymes. For example, the catalase (CAT) activity in the cell extract of E. oxidotolerans $\mathrm{T}-2-2^{\mathrm{T}}$ is 567 times higher than that of E. coli [23]. The activity of superoxide dismutase (SOD) purified from Exiguobacterium sp. OS-77 is 1.4 and 7.5 times higher than those of E. coli and Thermus thermophiles, respectively [27]. The involvement of carotenoids and highly active antioxidant enzymes in the protection of Exiguobacterium sp. from ROS and NOS can also be expected. Pantoea sp. and E. coli are Gram-negative bacteria, and the peptidoglycan layer of these cells is thin (1-10 nm) [78], which makes them susceptible to damage by ozone and other reactive species. Similar to several carotenoid-producing strains $[79,80]$, Pantoea sp. formed yellow colonies (Figure 1b). Other strains also exhibit the enzymatic activities of glutathione-S-transferase (GST) [81], CAT [81,82], and SOD [81,83]. Although the ability of Pantoea sp. to produce carotenoids and antioxidant enzymes is expected, the activities of these molecules seem to be insufficient to detoxify ROS and NOS. Normally, E. coli does not synthesize carotenoids [84], as there is no defense system by this antioxidant. Although the microorganism can produce CAT [85], SOD [85], glutathione reductase (GR) [86], GST [87], and glutathione peroxidase (GPX) [88], the activity of these antioxidant enzymes may not be sufficient to quench ROS and NOS.

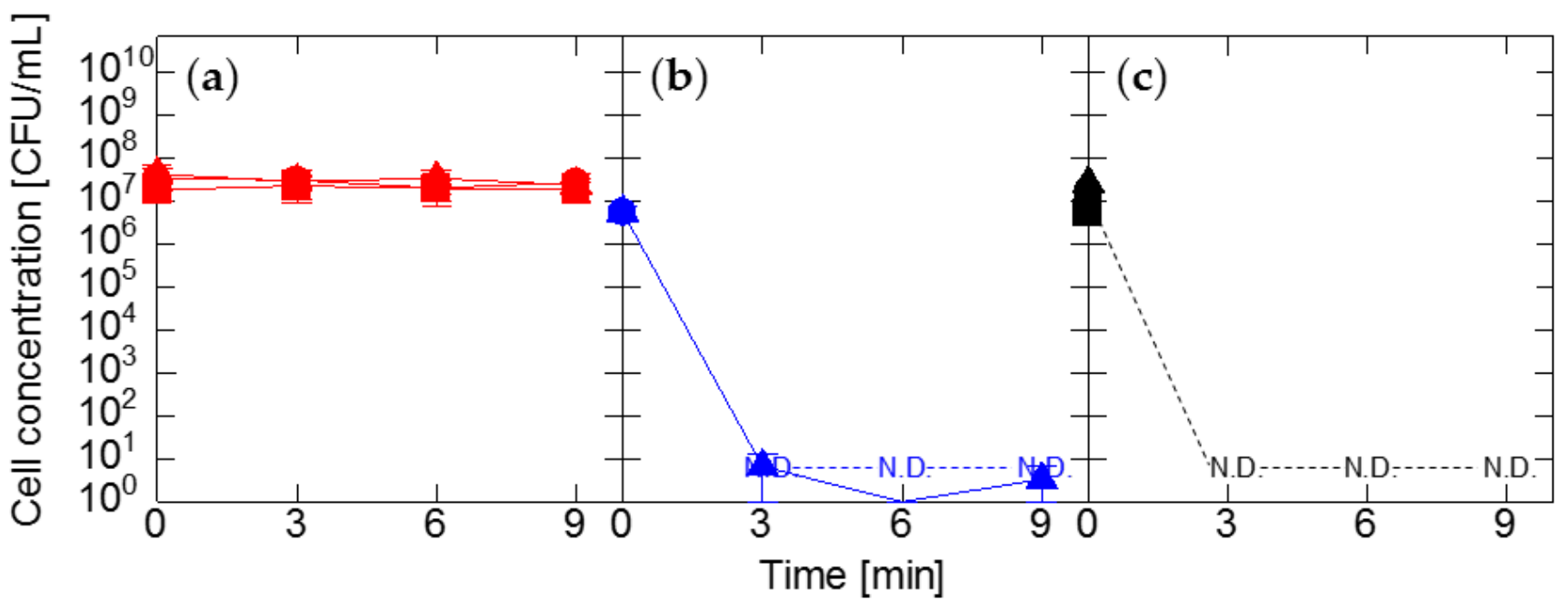

Figure 8. Effect of ozonated water treatment on Exiguobacterium sp. (a), Pantoea sp. (b), and E. coli (c). Symbols indicate concentrations of 0.5 ppm (closed circles), 1 ppm (closed triangles), and 1.5 ppm (closed squares). N.D. means not detected.

\subsubsection{UV Irradiation}

UV disinfection is based on DNA damage that leads to an inhibition of DNA replication $[89,90]$. It can be utilized as a potential non-thermal technique for inactivating the pathogenic and spoilage microorganisms in the food industry [90]. UV is classified into UVA (320-400 nm), UVB (280-320 nm), and UVC (190-280 nm) [91]. Among them, UVC is commonly used due to its excellent germicidal properties [90]. In this study, the bactericidal effect of UV irradiation was evaluated by using a germicidal lamp that emits UVC at around $254 \mathrm{~nm}$. No bactericidal effect against Exiguobacterium sp. was observed, even after irradiation for $3 \mathrm{~min}$ (Figure 9a). In contrast, the viable cell densities of Pantoea sp. and E. coli were reduced over time and were not detected at 2 min or thereafter (Figure 9b,c). Exiguobacterium sp. was found to be UV-resistant; therefore, particular attention should be paid to the contamination of this microorganism in food factories, where microbial disinfection has been performed by UV irradiation. The sensitivity of Pantoea sp. to UV irradiation was similar to that of E. coli. The mechanisms underlying the bactericidal effect of UVC are explained as follows: UVC irradiation leads to the formation of cyclobutane-type pyrimidine dimers, the $(6,4)$ photoproduct (and corresponding Dewar isomer), and thymine glycols [92]. In addition, singlet oxygen generated by UVC causes 8-oxoguanine (8-oxoG) [93]. Such damage to DNA can block replication and can result in cell inactivation. In prokaryotes, these 
lesions are repaired by various pathways, such as nucleotide excision repair (NER) [94-98], base excision repair (BER) [99-101], methyl-directed mismatch repair (MMR) [96,102-104], UV damage endonuclease-dependent excision repair (UVER) [105], SOS response [97], and photoreactivation [106]. Numerous DNA repair enzymes are involved in these pathways. In addition, singlet oxygen-induced DNA damage can be reduced by carotenoids [107]. Therefore, the sensitivities of these microorganisms to UV irradiation might be related to the activities of DNA repair enzymes and antioxidants. Although DNA repair enzymes of bacteria belonging to the genus Exiguobacterium have not yet been fully elucidated, genes encoding UvrABC [108,109], MutM [109], MutS-MutL [108,109], SSB [109], LexA [109], RuvAB [109], and photolyase [108,109] have been identified in a few strains of the same genus. As noted above, the characteristic of Exiguobacterium sp. to form orange colonies (Figure 1a) was consistent with several carotenoid-producing strains [24,25]. It is presumed that Exiguobacterium sp. also has DNA repair enzymes and carotenoids, and their superior activities, may be responsible for the resistance to UV irradiation. In the case of bacteria belonging to the genus Pantoea, only one gene encoding photolyase has been identified in P. agglomerans [110]. It is believed that some of the DNA repair pathways (NER, BER, and MMR) are highly conserved from bacteria to human [98,101,104]. Thus, Pantoea sp. may have a number of DNA repair enzymes. This microorganism may also have carotenoids because they form yellow colonies (Figure 1b), similar to other carotenoid-producing strains $[79,80]$. However, the activities of these molecules might not be sufficient to protect against UV and singlet oxygen-induced DNA damage. E. coli has a wide variety of DNA repair enzymes [94-97,99-104,106], but does not have carotenoids [84]. This microorganism is thought to be inactivated due to the insufficient activity of these enzymes and the absence of the defense system by carotenoids.

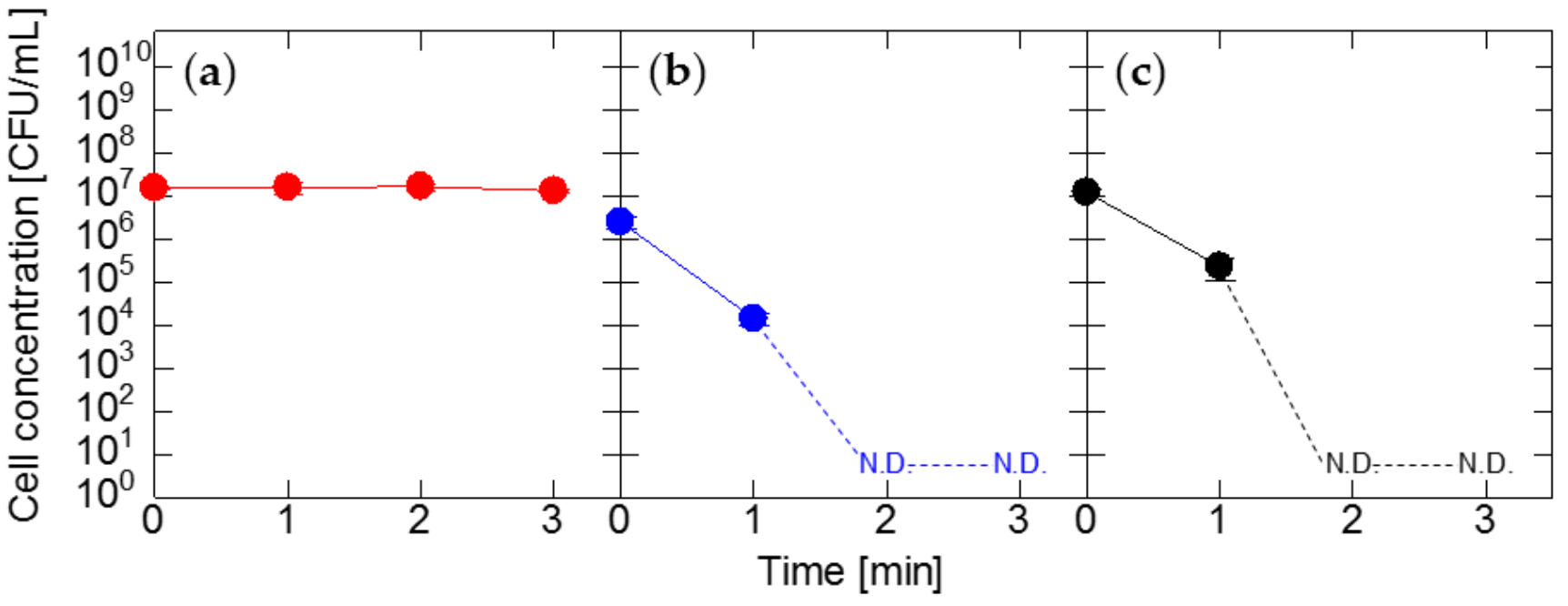

Figure 9. Effect of UV irradiation on Exiguobacterium sp. (a), Pantoea sp. (b), and E. coli (c). N.D. means not detected.

\subsubsection{PEF Treatment}

PEF treatment is a non-thermal bactericidal method that can minimize the loss of taste, aroma, color, and nutrients in food [111,112]. The inactivation of the microorganism is achieved by the electrical breakdown of the cell membranes during exposure to electric fields. The lethal effect of PEF treatment is dependent on the electric field strength and the treatment time [113]. When the cell suspensions of each microorganism were treated with PEF at the electric field strength of $15 \mathrm{kV} / \mathrm{cm}$ for $1 \mathrm{~min}$, the viable cell densities of Exiguobacterium sp. and Pantoea sp. decreased by about $5 \log$ and $4 \log \mathrm{CFU} / \mathrm{mL}$, respectively (Figure 10a,b). In contrast, no bactericidal effect against $E$. coli was observed (Figure 10c). Since the temperatures of these cell suspensions reached the lethal level of the respective microorganisms (approximately $50^{\circ} \mathrm{C}$ ), it is necessary to think about the effect 
of heat on the bactericidal effect. In the heat treatment experiment, about $1 \log$ and $2 \log$ reductions in CFU/mL for Exiguobacterium sp. and Pantoea sp., respectively, were observed at $50{ }^{\circ} \mathrm{C}$ for $5 \mathrm{~min}$ (Figure 3a,b). If the treatment is completed within $1 \mathrm{~min}$, the decrease in the number of viable cells is estimated to be more suppressed. Therefore, the bactericidal effect against each microorganism observed here is not considered to be due only to the generated heat. The possibility of the combined effects of heat and PEF treatment on the bactericidal effect $[111,114]$ should be considered. Exiguobacterium sp. and Pantoea sp. were inactivated by PEF treatment that did not cause lethal damage to E. coli. As we discussed in the previous work [111], the sensitivity of microorganisms to PEF treatment is considered to be dependent on the difference in the stability of cell membranes. Since Exiguobacterium sp. and Pantoea sp. were cultured at $4{ }^{\circ} \mathrm{C}$, their cell membranes should become fragile due to the relatively high content of unsaturated fatty acid in phospholipid molecules. Thus, they become more sensitive to PEF treatment. The results obtained here show good agreement with our previous work and support our hypothesis that the bactericidal effect of PEF treatment depends on the culture temperature of the objective microorganism [111]. Because PEF would primarily attack the cell membrane, this method may also be applicable to the inactivation of other cold-tolerant microorganisms.

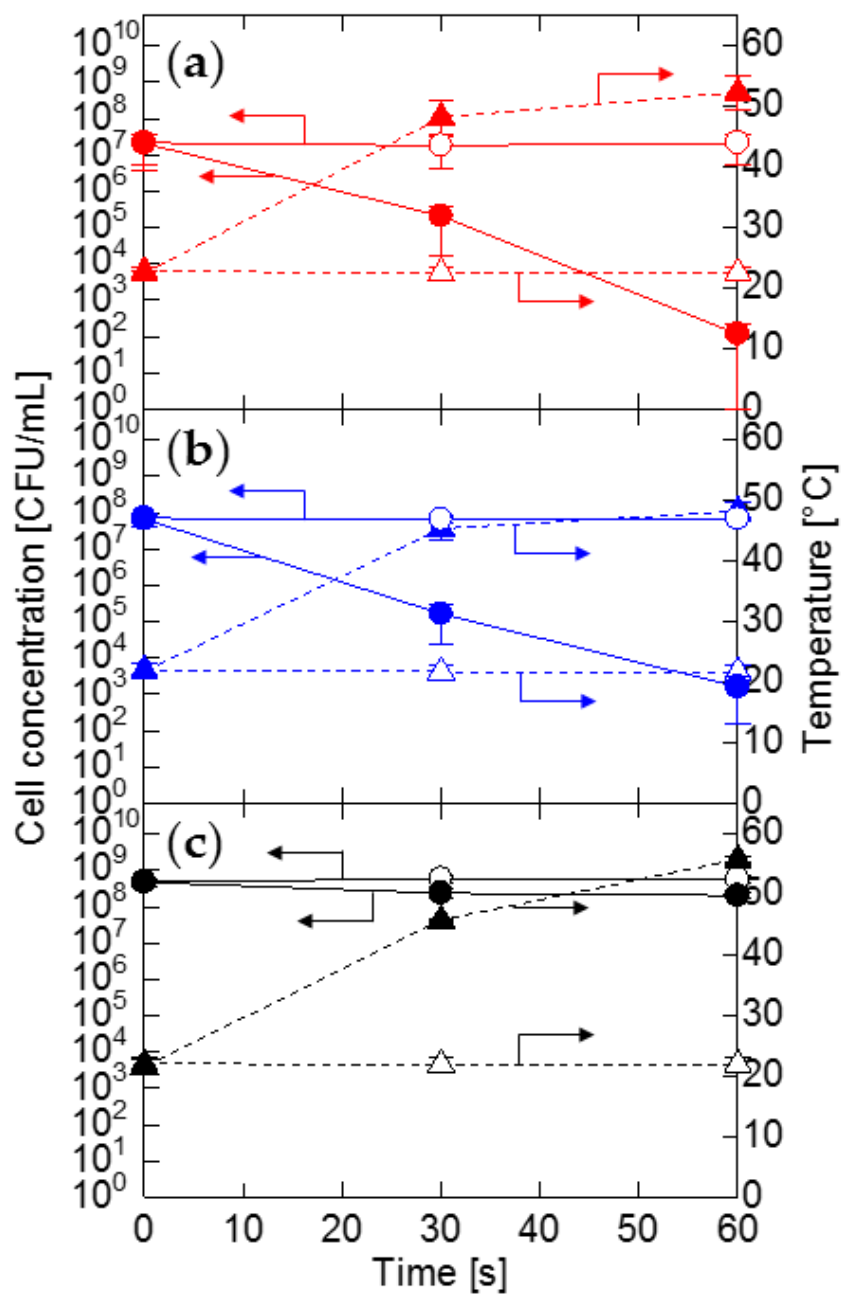

Figure 10. Effect of PEF treatment on Exiguobacterium sp. (a), Pantoea sp. (b), and E. coli (c). Symbols indicate cell concentration of PEF treated sample (closed circles), temperature of PEF treated sample (closed triangles), cell concentration of sample without PEF treatment (open circles), and temperature of sample without PEF treatment (open triangles). 


\subsubsection{Sensitivities of Each Microorganism to Various Bactericidal Methods}

Table 1 shows the condition of each bactericidal method in which the highest bactericidal effect was obtained. Exiguobacterium sp. was sensitive to heat, sodium hypochlorite, acetic acid, citric acid, and PEF, but resistant to sodium hydroxide, ozonated water, and UV. The sensitivities of Pantoea sp. to various bactericidal methods were almost similar to those of E. coli, except for the responses to PEF. Pantoea sp. was inactivated at a lower temperature and a lower concentration of sodium hypochlorite than $E$. coli. The former was sensitive and the latter was insensitive to PEF.

Table 1. Comparison of the effects of various bactericidal methods.

\begin{tabular}{cccc}
\hline Treatment & Exiguobacterium sp. & Pantoea sp. & E. coli \\
\hline Heat & $50{ }^{\circ} \mathrm{C}, 15 \mathrm{~min}$ & $50^{\circ} \mathrm{C}, 10 \mathrm{~min}$ & $55^{\circ} \mathrm{C}, 20 \mathrm{~min}$ \\
Sodium hypochlorite & $2 \mathrm{ppm}, 30 \mathrm{~s}$ & $2 \mathrm{ppm}, 3 \mathrm{~min}$ & $5 \mathrm{ppm}, 3 \mathrm{~min}$ \\
Acetic acid & $30 \mathrm{~s}$ & No bactericidal effect & No bactericidal effect \\
Citric acid & $30 \mathrm{~s}$ & No bactericidal effect & No bactericidal effect \\
Sodium hydroxide & No bactericidal effect & No bactericidal effect & No bactericidal effect \\
Ozonated water & No bactericidal effect & $0.5 \mathrm{ppm}, 3 \mathrm{~min}$ & 0.5 ppm, 3 min \\
UV & No bactericidal effect & $2 \mathrm{~min}$ & 2 min \\
PEF & $>1$ min & $>1 \mathrm{~min}$ & No bactericidal effect \\
\hline
\end{tabular}

\section{Conclusions}

Exiguobacterium sp. and Pantoea sp. were isolated from an ozonated immersion solution of packed tofu, stored at $4{ }^{\circ} \mathrm{C}$ for 6 days. These microorganisms were classified as psychrotrophic bacteria, according to their ability to grow at $4{ }^{\circ} \mathrm{C}$ and optimum growth temperature of $30^{\circ} \mathrm{C}$. Equipment and workers are considered to be the potential sources and risk factors for the microbial contamination of tofu.

Exiguobacterium sp. was sensitive to heat, sodium hypochlorite, acetic acid, citric acid, and PEF, but resistant to sodium hydroxide, ozonated water, and UV. Therefore, particular attention should be paid to the contamination of this microorganism in food factories where cleaning, sanitizing, and microbial disinfection are performed by ozonated water and UV irradiation. The resistance of Exiguobacterium sp. to ozonated water was probably due to the presence of a thick peptidoglycan layer and the defense systems of carotenoids and highly active antioxidant enzymes. The superior activities of DNA repair enzymes and carotenoids may be responsible for the resistance of this microorganism to UV irradiation. Pantoea sp. was sensitive to heat, sodium hypochlorite, ozonated water, UV, and PEF, but resistant to acetic acid, citric acid, and sodium hydroxide. The resistance of this microorganism to organic acids may be derived from natural acid resistance and/or the ATR system. Exiguobacterium sp. and Pantoea sp. were resistant to sodium hydroxide. This result suggests the risk that alkaline sanitizers are ineffective to these microorganisms. However, if the alkaline sanitizers contain other biocidal reagents, such as $\mathrm{HOCl}$ and - $\mathrm{OCl}$, the bactericidal effect should be expected. Both Exiguobacterium sp. and Pantoea sp. were inactivated by PEF treatment that did not cause lethal damage to $E$. coli. Since these microorganisms were cultured at $4{ }^{\circ} \mathrm{C}$, their cell membranes should become fragile due to the relatively high content of unsaturated fatty acid in phospholipid molecules. Thus, they become more sensitive to PEF treatment.

From this research, we have provided practical recommendations for the improvement of the microbial safety and quality of tofu in the manufacturing process. Equipment should be cleaned, sanitized, and disinfected by heat treatment and sodium hypochlorite. The workers are required to sanitize their hands with organic acids and ozonated water. PEF treatment of the water for cooling, washing, and packing of the tofu blocks could also be effective to prevent or minimize microbial contamination.

The results obtained in this study suggest that bactericidal methods targeting the fragile cell membrane with high permeability are effective for the inactivation of coldtolerant microorganisms. In particular, PEF treatment can be applied as a powerful tool for 
the inactivation of cold-tolerant microorganisms. This method may contribute to enhancing the microbiological safety and quality of various foods under refrigeration conditions.

Author Contributions: Conceptualization, T.T. and T.O.; methodology, M.M., T.T. and T.O.; software, A.G., K.T. (Katsuyuki Takahashi) and K.T. (Koichi Takaki); validation, A.G., K.T. (Katsuyuki Takahashi) and K.T. (Koichi Takaki); formal analysis, A.G., K.T. (Katsuyuki Takahashi) and K.T. (Koichi Takaki); investigation, M.M., T.T., M.I., C.N. and T.O.; resources, M.M., T.T. and T.O.; data curation, M.M., T.T., M.I., C.N. and T.O.; writing-original draft preparation, M.M., T.T. and T.O.; writing-review and editing, M.M., T.T., A.G., K.T. (Katsuyuki Takahashi), K.T. (Koichi Takaki) and T.O.; visualization, M.M., T.T., M.I., C.N. and T.O.; supervision, K.T. (Koichi Takaki) and T.O.; project administration, K.T. (Koichi Takaki) and T.O.; funding acquisition, K.T. (Katsuyuki Takahashi), K.T. (Koichi Takaki) and T.O. All authors have read and agreed to the published version of the manuscript.

Funding: This research was funded by a Grant-in-Aid for Scientific Research (S) from the Japan Society for the Promotion of Science, Grant Number 19H05611.

Data Availability Statement: Not applicable.

Conflicts of Interest: The authors declare no conflict of interest.

\section{References}

1. McLauchlin, J. Life and death of micro-organisms in food, spoilage and preservation. In Hobb's Food Poisoning and Food Hygiene, 7th ed.; McLauchlin, J., Little, C., Eds.; CRC Press: London, UK, 2007; pp. 41-58.

2. Adam, K.H.; Flint, S.H.; Brightwell, G. Psychrophilic and psychrotrophic clostridia: Sporulation and germination processes and their role in the spoilage of chilled, vacuum-packaged beef, lamb and venison: A Review. Int. J. Food Sci. Technol. 2010, 45, 1539-1544. [CrossRef]

3. Rossi, F.; Felis, G.E.; Martinelli, A.; Calcavecchia, B.; Torriani, S. Microbial characteristics of fresh tofu produced in small industrial scale and identification of specific spoiling microorganisms (SSO). LWT-Food Sci. Technol. 2016, 70, 280-285. [CrossRef]

4. Lee, S.; Cho, H.; Lee, K.-G. Volatile compounds as makers of tofu (soybean curd) freshness during storage. J. Agric. Food Chem. 2014, 62, 772-779. [CrossRef] [PubMed]

5. Kovats, S.K.; Doyle, M.P.; Tanaka, N. Evaluation of the microbiological safety of tofu. J. Food Prot. 1984, 47, 618-622. [CrossRef] [PubMed]

6. Zheng, L.; Regenstein, J.M.; Teng, F.; Li, Y. Tofu products: A review of their raw materials, processing conditions, and packaging. Compr. Rev. Food Sci. Food Saf. 2020, 19, 3683-3714. [CrossRef]

7. Fouad, K.E.; Hegeman, G.D. Microbial spoilage of tofu (soybean curd). J. Food Prot. 1993, 56, 157-164. [CrossRef]

8. Tuitemwong, K.; Fung, D.Y.C. Microbiological study of tofu. J. Food Prot. 1991, 54, 212-216. [CrossRef] [PubMed]

9. Lee, D.-Y.; Kwon, K.-H.; Chai, C.; Oh, S.-W. Microbial contamination of tofu in Korea and growth characteristics of Bacillus cereus isolates in Tofu. LWT 2017, 78, 63-69. [CrossRef]

10. Kwon, M.J.; Rhee, M.S.; Yoon, K.S. A risk assessment study of Bacillus cereus in packaged tofu at a retail market in Korea. Food Sci. Biotechnol. 2020, 29, 339-350. [CrossRef]

11. Allende, A.; Truchado, P.; Lindqvist, R.; Jacxsens, L. Quantitative microbial exposure modelling as a tool to evaluate the impact of contamination level of surface irrigation water and seasonality on fecal hygiene indicator E. coli in leafy green production. Food Microbiol. 2018, 75, 82-89. [CrossRef]

12. Rapid identification of microorganisms based on molecular biological method. In The Japanese Phermacopoeia, 15th ed.; Society of Japanese Pharmacopoeia (Ed.) Yakuji Nippo, Ltd.: Tokyo, Japan, 2006; pp. 1741-1742.

13. Collins, M.D.; Lund, B.M.; Farrow, J.A.E.; Schleifer, K.H. Chemotaxonomic study of an alkalophilic bacterium, Exiguobacterium aurantiacum gen. nov., sp. nov. Microbiology 1983, 129, 2037-2042. [CrossRef]

14. Vishnivetskaya, T.A.; Siletzky, R.; Jefferies, N.; Tiedje, J.M.; Kathariou, S. Effect of low temperature and culture media on the growth and freeze-thawing tolerance of Exiguobacterium strains. Cryobiology 2007, 54, 234-240. [CrossRef]

15. Frühling, A.; Schumann, P.; Hippe, H.; Sträubler, B.; Stackebrandt, E. Exiguobacterium undae sp. nov. and Exiguobacterium antarcticum sp. nov. Int. J. Syst. Evol. Microbiol. 2002, 52, 1171-1176.

16. Raichand, R.; Pareek, S.; Singh, N.K.; Mayilraj, S. Exiguobacterium aquaticum sp. nov., a member of the genus Exiguobacterium. Int. J. Syst. Evol. Microbiol. 2012, 62, 2150-2155. [CrossRef]

17. Kim, I.-G.; Lee, M.-H.; Jung, S.-Y.; Song, J.J.; Oh, T.-K.; Yoon, J.-H. Exiguobacterium aestuarii sp. nov. and Exiguobacterium marinum sp. nov., islated from a tidal flat of the Yellow Sea in Korea. Int. J. Syst. Evol. Microbiol. 2005, 55, 885-889. [CrossRef] [PubMed]

18. Ponder, M.A.; Gilmour, S.J.; Bergholz, P.W.; Mindock, C.A.; Hollingsworth, R.; Thomashow, M.F.; Tiedje, J.M. Characterization of potential stress responses in ancient Siberian permafrost psychroactive bacteria. FEMS Microbiol. Ecol. 2005, 53, 103-115. [CrossRef] [PubMed] 
19. Rodrigues, D.F.; Goris, J.; Vishnivetskaya, T.; Gilichinsky, D.; Thomashow, M.F.; Tiedje, J.M. Characterization of Exiguobacterium isolates from the Siberian permafrost. Description of Exiguobacterium sibiricum sp. nov. Extremophiles 2006, 10, 285-294. [CrossRef]

20. Vishnivetskaya, T.A.; Kathariou, S.; Tiedje, J.M. The Exiguobacterium genus: Biodiversity and biogeography. Extremophiles 2009, 13, 541-555. [CrossRef]

21. Sen, S.K.; Jana, A.; Bandyopadhyay, P.; Mohapatra, P.K.D.; Raut, S. Thermostable amylase production from hot spring isolate Exiguobacterium sp: A promising agent for natural detergents. Sustain. Chem. Pharm. 2016, 3, 59-68. [CrossRef]

22. Gee, J.M.; Lund, B.M.; Metcalf, G.; Peel, J.L. Properties of a new group of alkalophilic bacteria. Microbiology 1980, 117, 9-17. [CrossRef]

23. Yumoto, I.; Hishinuma-Narisawa, M.; Hirota, K.; Shingyo, T.; Takebe, F.; Nodasaka, Y.; Matsuyama, H.; Hara, I. Exiguobacterium oxidotolerans sp. nov., a novel alkaliphile exhibiting high catalase activity. Int. J. Syst. Evol. Microbiol. 2004, 54, $2013-2017$. [CrossRef]

24. Flores, M.R.; Ordoñez, O.F.; Maldonado, M.J.; Farías, M.E. Isolation of UV-B resistant bacteria from two high altitude Andean lakes $(4400 \mathrm{~m})$ with saline and non saline conditions. J. Gen. Appl. Microbiol. 2009, 55, 447-458. [CrossRef] [PubMed]

25. Asker, D.; Beppu, T.; Ueda, K. Unique diversity of carotenoid-producing bacteria isolated from Misasa, a radioactive site in Japan. Appl. Microbiol. Biotechnol. 2007, 77, 383-392. [CrossRef] [PubMed]

26. Wannicke, N.; Frindte, K.; Gust, G.; Liskow, I.; Wacker, A.; Meyer, A.; Grossart, H.-P. Measuring bacterial activity and community composition at high hydrostatic pressure using a novel experimental approach: A pilot study. FEMS Microbiol. Ecol. 2015, 91, fiv036. [CrossRef]

27. Nonaka, K.; Yoon, K.-S.; Ogo, S. Biochemical characterization of psychrophilic Mn-superoxide dismutase from newly isolated Exiguobacterium sp. OS-77. Extremophiles 2014, 18, 363-373. [CrossRef]

28. Liu, F.; Wang, D.; Du, L.; Zhu, Y.; Xu, W. Diversity of the predominant spoilage bacteria in water-boiled salted duck during storage. J. Food Sci. 2010, 75, M317-M321. [CrossRef] [PubMed]

29. Kim, M.-H.; Khan, M.S.I.; Lee, K.-W.; Kim, Y.-J. Biofilm reduction potential of micro-plasma discharged water (m-PDW) against the microbes isolated from a tofu manufacturing plant. LWT 2018, 97, 719-724. [CrossRef]

30. Chauhan, H.; Bagyaraj, D.J.; Selvakumar, G.; Sundaram, S.P. Novel plant growth promoting rhizobacteria-Prospects and potential: A Review. Appl. Soil Ecol. 2015, 95, 38-53. [CrossRef]

31. Morohoshi, T.; Nakamura, Y.; Yamazaki, G.; Ishida, A.; Kato, N.; Ikeda, T. The plant pathogen Pantoea ananatis produces $\mathrm{N}$-acylhomoserine lactone and causes center rot disease of onion by quorum sensing. J. Bacteriol. 2007, 189, 8333-8338. [CrossRef]

32. Nicoletti, G.; Corbella, M.; Jaber, O.; Marone, P.; Scevola, D.; Faga, A. Non-pathogenic microflora of a spring water with regenerative properties. Biomed. Rep. 2015, 3, 758-762. [CrossRef]

33. Son, H.-J.; Park, G.-T.; Cha, M.-S.; Heo, M.-S. Solubilization of insoluble inorganic phosphates by a novel salt- and pH-tolerant Pantoea agglomerans R-42 isolated from soybean rhizosphere. Bioresour. Technol. 2006, 97, 204-210. [CrossRef]

34. Vasileva-Tonkova, E.; Gesheva, V. Biosurfactant production by antarctic facultative anaerobe Pantoea sp. during growth on hydrocarbons. Curr. Microbiol. 2007, 54, 136-141. [CrossRef]

35. Dastager, S.G.; Deepa, C.K.; Puneet, S.C.; Nautiyal, C.S.; Pandey, A. Isolation and characterization of plant growth-promoting strain Pantoea NII-186. from Western Ghat forest soil, India. Lett. Appl. Microbiol. 2009, 49, 20-25. [CrossRef]

36. Völksch, B.; Ullrich, M.; Fritsche, W. Occurrence of antimicrobial activities of bacteria from soybean leaf spots. J. Basic Microbiol. 1993, 33, 349-355. [CrossRef]

37. Völksch, B.; Nüske, J.; May, R. Characterization of two epiphytic bacteria from soybean leaves with antagonistic activities against Pseudomonas syringae pv. glycinea. J. Basic Microbiol. 1996, 36, 453-462. [CrossRef] [PubMed]

38. May, R.; Völksch, B.; Kampmann, G. Antagonistic activities of epiphytic bacteria from soybean leaves against Pseudomonas syringae pv. glycinea in vitro and in planta. Microb. Ecol. 1997, 34, 118-124. [CrossRef] [PubMed]

39. Costa, E.; Usall, J.; Teixidó, N.; Delgado, J.; Viñas, I. Water activity, temperature, and pH effects on growth of the biocontrol agent Pantoea agglomerans strain CPA-2. Can. J. Microbiol. 2002, 48, 1082-1088. [CrossRef]

40. Gitaitis, R.; Walcott, R.; Culpepper, S.; Sanders, H.; Zolobowska, L.; Langston, D. Recovery of Pantoea ananatis, causal agent of center rot of onion, from weeds and crops in Georgia, USA. Crop Prot. 2002, 21, 983-989. [CrossRef]

41. Asis, C.A., Jr.; Adachi, K. Isolation of endophytic diazotroph Pantoea agglomerans and nondiazotroph Enterobacter asburiae from sweetpotato stem in Japan. Lett. Appl. Microbiol. 2003, 38, 19-23. [CrossRef]

42. Feng, Y.; Shen, D.; Song, W. Rice endophyte Pantoea agglomerans YS19 promotes host plant growth and affects allocations of host photosynthates. J. Appl. Microbiol. 2006, 100, 938-945. [CrossRef] [PubMed]

43. Medrano, E.G.; Bell, A.A. Role of Pantoea agglomerans in opportunistic bacterial seed and boll rot of cotton (Gossypium hirsutum) grown in the field. J. Appl. Microbiol. 2007, 102, 134-143. [CrossRef] [PubMed]

44. Enya, J.; Shinohara, H.; Yoshida, S.; Tsukiboshi, T.; Negishi, H.; Suyama, K.; Tsushima, S. Culturable leaf-associated bacteria on tomato plants and their potential as biological control agents. Microb. Ecol. 2007, 53, 524-536. [CrossRef] [PubMed]

45. Quecine, M.C.; Araújo, W.L.; Rossetto, P.B.; Ferreira, A.; Tsui, S.; Lacava, P.T.; Mondin, M.; Azevedo, J.L.; Pizzirani-Kleiner, A.A. Sugarcane growth promotion by the endophytic bacterium Pantoea agglomerans 33.1. Appl. Environ. Microbiol. 2012, 78, 7511-7518. [CrossRef] [PubMed]

46. Baere, T.D.; Verhelst, R.; Labit, C.; Verschraegen, G.; Wauters, G.; Claeys, G.; Vaneechoutte, M. Bacterial infection with Pantoea ananatis. J. Clin. Microbiol. 2004, 42, 4393-4395. [CrossRef] 
47. Cruz, A.T.; Cazacu, A.C.; Allen, C.H. Pantoea agglomerans, a plant pathogen causing human disease. J. Clin. Microbiol. 2007, 45, 1989-1992. [CrossRef] [PubMed]

48. Hong, C.B.; Donahue, J.M.; Giles, R.C., Jr.; Petrites-Murphy, M.B.; Poonacha, K.B.; Roberts, A.W.; Smith, B.J.; Tramontin, R.R.; Tuttle, P.A.; Swerczek, T.W. Etiology and pathology of equine placentitis. J. Vet. Diagn. Invest. 1993, 5, 56-63. [CrossRef] [PubMed]

49. Verdier-Metz, I.; Gagne, G.; Bornes, S.; Monsallier, F.; Veisseire, P.; Delbès-Paus, C.; Montel, M.-C. Cow teat skin, a potential source of diverse microbial populations for cheese production. Appl. Environ. Microbiol. 2012, 78, 326-333. [CrossRef]

50. Kozloff, L.M.; Schofield, M.A.; Lute, M. Ice nucleating activity of Pseudomonas syringae and Erwinia herbicola. J. Bacteriol. 1983, 153, 222-231. [CrossRef]

51. Michigami, Y.; Abe, K.; Iwabuchi, K.; Obata, H.; Arai, S. Formation of ice nucleation-active vesicles in Erwinia uredovora at low temperature and transport of InaU molecules into shed vesicles. Biosci. Biotech. Biochem. 1995, 59, 1996-1998. [CrossRef]

52. Fujikawa, H.; Akimoto, R. New blue pigment produced by Pantoea agglomerans and its production characteristics at various temperatures. Appl. Environ. Microbiol. 2011, 77, 172-178. [CrossRef] [PubMed]

53. Morita, R.Y. Psychrophilic bacteria. Bacteriol. Rev. 1975, 39, 144-167. [CrossRef]

54. Cebrián, G.; Condón, S.; Mañas, P. Physiology of the inactivation of vegetative bacteria by thermal treatments: Mode of action, influence of environmental factors and inactivation kinetics. Foods 2017, 6, 107. [CrossRef] [PubMed]

55. Beuchat, L.R.; Nail, B.V.; Adler, B.B.; Clavero, M.R.S. Efficasy of spray application of chlorinated water in killing pathogenic bacteria on raw apples, tomatoes, and lettuce. J. Food Prot. 1998, 61, 1305-1311. [CrossRef]

56. Baur, S.; Klaiber, R.; Hammes, W.P.; Carle, R. Sensory and microbiological quality of shredded, packaged iceberg lettuce as affected by pre-washing procedures with chlorinated and ozonated water. Innov. Food Sci. Emerg. Technol. 2004, 5, 45-55. [CrossRef]

57. Fukuzaki, S. Mechanisms of actions of sodium hypochlorite in cleaning and disinfection processes: A Review. Biocontrol. Sci. 2006, 11, 147-157. [CrossRef]

58. Russell, N.J.; Fukunaga, N. A comparison of thermal adaptation of membrane lipids in psychrophilic and thermophilic bacteria: A Review. FEMS Microbiol. Rev. 1990, 75, 171-182. [CrossRef]

59. Théberge, M.-C.; Prévost, D.; Chalifour, F.-P. The effect of different temperatures on the fatty acid composition of Rhizobium leguminosarum bv. viciae in the faba bean symbiosis. New Phytol. 1996, 134, 657-664. [CrossRef]

60. Fukunaga, N.; Russell, N.J. Membrane lipid composition and glucose uptake in two psychrotolerant bacteria from Antarctica. J. Gen. Microbiol. 1990, 136, 1669-1673. [CrossRef]

61. Mansilla, M.C.; Cybulski, L.E.; Albanesi, D.; de Mendoza, D. Control of membrane lipid fluidity by molecular thermosensors: A Review. J. Bacteriol. 2004, 186, 6681-6688. [CrossRef] [PubMed]

62. Levine, A.S.; Fellers, C.R. Action of acetic acid on food spoilage microorganisms. J. Bacteriol. 1940, 39, 499-515. [CrossRef]

63. Ryssel, H.; Kloeters, O.; Germann, G.; Schäfer, T.; Wiedemann, G.; Oehlbauer, M. The antimicrobial effect of acetic acid-An alternative to common local antiseptics? Burns 2009, 35, 695-700. [CrossRef] [PubMed]

64. Thippareddi, H.; Juneja, V.K.; Phebus, R.K.; Marsden, J.L.; Kastner, C.L. Control of Clostridium perfringens germination and outgrowth by buffered sodium citrate during chilling of roast beef and injected pork. J. Food Prot. 2003, 66, 376-381. [CrossRef] [PubMed]

65. Akbas, M.Y.; Ölmez, H. Inactivation of Escherichia coli and Listeria monocytogenes on iceberg lettuce by dip wash treatments with organic acids. Lett. Appl. Microbiol. 2007, 44, 619-624. [CrossRef]

66. Fellows, P.J. Food Processing Technology: Principles and Practice, 4th ed.; Woodhead Publishing: Duxford, UK, 2016 ; pp. 50-53.

67. Salmond, C.V.; Kroll, R.G.; Booth, I.R. The effect of food preservatives on pH homeostasis in Escherichia coli. Microbiology 1984, 130, 2845-2850. [CrossRef]

68. Roe, A.J.; O'Byrne, C.; McLaggan, D.; Booth, I.R. Inhibition of Escherichia coli growth by acetic acid: A problem with methionine biosynthesis and homocysteine toxicity. Microbiology 2002, 148, 2215-2222. [CrossRef]

69. Chun, A.Y.; Yunxiao, L.; Ashok, S.; Seol, E.; Park, S. Elucidation of toxicity of organic acids inhibiting growth of Escherichia coli W. Biotechnol. Bioprocess Eng. 2014, 19, 858-865. [CrossRef]

70. Kundukad, B.; Udayakumar, G.; Grela, E.; Kaur, D.; Rice, S.A.; Kjelleberg, S.; Doyle, P.S. Weak acids as an alternative anti-microbial therapy. Biofilm 2020, 2, 100019. [CrossRef]

71. Cañamás, T.P.; Viñas, I.; Abadias, M.; Usall, J.; Torres, R.; Teixidó, N. Acid tolerance response induced in the biocontrol agent Pantoea agglomerans CPA-2 and effect on its survival ability in acidic environments. Microbiol. Res. 2009, 164, 438-450. [CrossRef] [PubMed]

72. Malik, Y.S.; Goyal, S.M. Virucidal efficacy of sodium bicarbonate on a food contact surface against feline calicivirus, a norovirus surrogate. Int. J. Food Microbiol. 2006, 109, 160-163. [CrossRef]

73. Abadias, M.; Usall, J.; Oliveira, M.; Alegre, I.; Viñas, I. Efficacy of neutral electrolyzed water (NEW) for reducing microbial contamination on minimally-processed vegetables. Int. J. Food Microbiol. 2008, 123, 151-158. [CrossRef]

74. Naito, S.; Takahara, H. Ozone contribution in food industry in Japan. Ozone Sci. Eng. 2006, 28, 425-429. [CrossRef]

75. Murray, B.K.; Ohmine, S.; Tomer, D.P.; Jensen, K.J.; Johnson, F.B.; Kirsi, J.J.; Robison, R.A.; O'Neill, K.L. Virion disruption by ozone-mediated reactive oxygen species. J. Virol. Methods 2008, 153, 74-77. [CrossRef]

76. Ersoy, G.E.; Barisci, S.; Dinc, O. Mechanism of the Escherichia coli and Enterococcus faecalis inactivation by ozone. LWT 2019, 100, 306-313. [CrossRef] 
77. Guzel-Seydim, Z.B.; Greene, A.K.; Seydim, A.C. Use of ozone in the food industry: A Review. LWT-Food Sci. Technol. 2004, 37, 453-460. [CrossRef]

78. Elbourne, A.; Chapman, J.; Gelmi, A.; Cozzolino, D.; Crawford, R.J.; Truong, V.K. Bacterial-nanostructure interactions: The role of cell elasticity and adhesion forces. J. Colloid Interface Sci. 2019, 546, 192-210. [CrossRef] [PubMed]

79. Dussault, D.; Caillet, S.; Tien, C.L.; Lacroix, M. Carotenoids' influence on radiotolerance of Pantoea agglomerans, a plant pathogen. Lett. Appl. Microbiol. 2008, 47, 208-213. [CrossRef]

80. Mohammadi, M.; Burbank, L.; Roper, M.C. Biological role of pigment production for the bacterial phytopathogen Pantoea stewartii subsp. stewartii. Appl. Environ. Microbiol. 2012, 78, 6859-6865. [CrossRef]

81. Prione, L.P.; Olchanheski, L.R.; Tullio, L.D.; Santo, B.C.E.; Reche, P.M.; Martins, P.F.; Carvalho, G.; Demiate, I.M.; Pileggi, S.A.V.; Dourado, M.N.; et al. GST activity and membrane lipid saturation prevents mesotrione-induced cellular damage in Pantoea ananatis. AMB Express 2016, 6, 70. [CrossRef]

82. Zeida, M.; Wieser, M.; Yoshida, T.; Sugio, T.; Nagasawa, T. Purification and Characterization of gallic acid decarboxylase from Pantoea agglomerans T71. Appl. Environ. Microbiol. 1998, 64, 4743-4747. [CrossRef]

83. Le-Tien, C.; Lafortune, R.; Shareck, F.; Lacroix, M. DNA analysis of a radiotolerant bacterium Panotea agglomerans by FT-IR spectroscopy. Talanta 2007, 71, 1969-1975. [CrossRef]

84. Pecker, I.; Chamovitz, D.; Linden, H.; Sandmann, G.; Hirschberg, J. A single polypeptide catalyzing the conversion of phytoene to $\zeta$-carotene is transcriptionally regulated during tomato fruit ripening. Proc. Natl. Acad. Sci. USA 1992, 89, 4962-4966. [CrossRef]

85. Schwartz, C.E.; Krall, J.; Norton, L.; McKay, K.; Kay, D.; Lynch, R.E. Catalase and superoxide dismutase in Escherichia coli: Roles in resistance to killing by neutrophils. J. Biol. Chem. 1983, 258, 6277-6281. [CrossRef]

86. Asnis, R.E. A glutathione reductase from Escherichia coli. J. Biol. Chem. 1955, 213, 77-85. [CrossRef]

87. Nishida, M.; Kong, K.-H.; Inoue, H.; Takahashi, K. Molecular cloning and site-directed mutagenesis of glutathione S-transferase from Escherichia coli. The conserved tyrosyl residue near the $\mathrm{N}$ terminus is not essential for catalysis. J. Biol. Chem. 1994, 269, 32536-32541. [CrossRef]

88. Arenas, F.A.; Díaz, W.A.; Leal, C.A.; Pérez-Donoso, J.M.; Imlay, J.A.; Vásquez, C.C. The Escherichia coli btuE gene, encodes a glutathione peroxidase that is induced under oxidative stress conditions. Biochem. Biophys. Res. Commun. 2010, 398, 690-694. [CrossRef]

89. Süß, J.; Volz, S.; Obst, U.; Schwartz, T. Application of a molecular biology concept for the detection of DNA damage and repair during UV disinfection. Water Res. 2009, 43, 3705-3716. [CrossRef] [PubMed]

90. Singh, H.; Bhardwaj, S.K.; Khatri, M.; Kim, K.-H.; Bhardwaj, N. UVC radiation for food safety: An emerging technology for the microbial disinfection of food products: A Review. Chem. Eng. J. 2021, 417, 128084. [CrossRef]

91. Tanaka, M.; Ohkubo, K.; Fukuzumi, S. Reductive DNA cleavage induced by UVA photoirradiation of NADH without oxygen. J. Am. Chem. Soc. 2006, 128, 12372-12373. [CrossRef] [PubMed]

92. Rath, D.; Mangoli, S.H.; Pagedar, A.R.; Jawali, N. Involvement of pnp in survival of UV radiation in Escherichia coli K-12. Microbiology 2012, 158, 1196-1205. [CrossRef]

93. Silva-Júnior, A.C.T.; Asad, L.M.B.O.; Felzenszwalb, I.; Asad, N.R. Mutagenicity induced by UVC in Escherichia coli cells: Reactive oxygen species involvement. Redox Rep. 2011, 16, 187-192. [CrossRef] [PubMed]

94. Sancar, A.; Rupp, W.D. A novel repair enzyme: UVRABC excision nuclease of Escherichia coli cuts a DNA strand on both sides of the damaged region. Cell 1983, 33, 249-260. [CrossRef]

95. Husain, I.; Van Houten, B.; Thomas, D.C.; Abdel-Monem, M.; Sancar, A. Effect of DNA polymerase I and DNA helicase II on the turnover rate of UvrABC excision nuclease. Proc. Natl. Acad. Sci. USA 1985, 82, 6774-6778. [CrossRef] [PubMed]

96. Mellon, I.; Champe, G.N. Products of DNA mismatch repair genes mutS and mutL are required for transcription-coupled nucleotide-excision repair of the lactose operon in Escherichia coli. Proc. Natl. Acad. Sci. USA 1996, 93, 1292-1297. [CrossRef] [PubMed]

97. Crowley, D.J.; Hanawalt, P.C. Induction of the SOS response increases the efficiency of global nucleotide excision repair of cyclobutane pyrimidine dimers, but not 6-4 photoproducts, in UV-irradiated Escherichia coli. J. Bacteriol. 1998, 180, 3345-3352. [CrossRef] [PubMed]

98. Bienstock, R.J.; Skorvaga, M.; Mandavilli, B.S.; Houten, B.V. Structural and functional characterization of the human DNA repair helicase XPD by comparative molecular modeling and site-directed mutagenesis of the bacterial repair protein UvrB. J. Biol. Chem. 2003, 278, 5309-5316. [CrossRef]

99. Hazra, T.K.; Muller, J.G.; Manuel, R.C.; Burrows, C.J.; Lloyd, R.S.; Mitra, S. Repair of hydantoins, one electron oxidation product of 8-oxoguanine, by DNA glycosylases of Escherichia coli. Nucleic Acids Res. 2001, 29, 1967-1974. [CrossRef]

100. Alanazi, M.; Leadon, S.A.; Mellon, I. Global genome removal of thymine glycol in Escherichia coli requires endonuclease III but the persistence of processed repair intermediates rather than thymine glycol correlates with cellular sensitivity to high doses of hydrogen peroxide. Nucleic Acids Res. 2002, 30, 4583-4591. [CrossRef] [PubMed]

101. Hegde, M.L.; Hazra, T.K.; Mitra, S. Early steps in the DNA base excision/single-strand interruption repair pathway in mammalian cells: A Review. Cell Res. 2008, 18, 27-47. [CrossRef] [PubMed]

102. Modrich, P. Mechanisms and biological effects of mismatch repair: A Review. Annu. Rev. Genet. 1991, 25, 229-253. [CrossRef]

103. Robertson, A.; Pattishall, S.R.; Matson, S.W. The DNA binding activity of MutL is required for methyl-directed mismatch repair in Escherichia coli. J. Biol. Chem. 2006, 281, 8399-8408. [CrossRef] 
104. Groothuizen, F.S.; Sixma, T.K. The conserved molecular machinery in DNA mismatch repair enzyme structures: A Review. DNA Repair 2016, 38, 14-23. [CrossRef] [PubMed]

105. Tanaka, M.; Narumi, I.; Funayama, T.; Kikuchi, M.; Watanabe, H.; Matsunaga, T.; Nikaido, O.; Yamamoto, K. Characterization of pathways dependent on the uvsE, uvrA1, or uvrA2 gene product for UV resistance in Deinococcus radiodurans. J. Bacteriol. 2005, 187, 3693-3697. [CrossRef]

106. Oguma, K.; Katayama, H.; Ohgaki, S. Photoreactivation of Echerichia coli after low- or medium-pressure UV disinfection determined by an endonuclease sensitive site assay. Appl. Environ. Microbiol. 2002, 68, 6029-6035. [CrossRef] [PubMed]

107. Gomes, A.A.; Silva-Júnior, A.C.T.; Oliveira, E.B.; Asad, L.M.B.O.; Reis, N.C.S.C.; Felzenszwalb, I.; Kovary, K.; Asad, N.R. Reactive oxygen species mediate lethality induced by far-UV in Escherichia coli cells. Redox Rep. 2005, 10, 91-95. [CrossRef]

108. Ordoñez, O.F.; Lanzarotti, E.; Kurth, D.; Gorriti, M.F.; Revale, S.; Cortez, N.; Vazquez, M.P.; Farías, M.E.; Turjanski, A.G. Draft genome sequence of the polyextremophilic Exiguobacterium sp. strain S17, isolated from hyperarsenic lakes in the Argentinian Puna. Genome Announc. 2013, 1, e00480-13. [CrossRef]

109. Castro-Severyn, J.; Remonsellez, F.; Valenzuela, S.L.; Salinas, C.; Fortt, J.; Aguilar, P.; Pardo-Esté, C.; Dorador, C.; Quatrini, R.; Molina, F.; et al. Comparative genomics analysis of a new Exiguobacterium strain from Salar de Huasco reveals a repertoire of stress-related genes and arsenic resistance. Front. Microbiol. 2017, 8, 456. [CrossRef] [PubMed]

110. Xu, L.; Tian, C.; Lu, X.; Ling, L.; Lv, J.; Wu, M.; Zhu, G. Photoreactivation of Escherichia coli is impaired at high growth temperatures. J. Photochem. Photobiol. B Biol. 2015, 147, 37-46. [CrossRef] [PubMed]

111. Ohshima, T.; Okuyama, K.; Sato, M. Effect of culture temperature on high-voltage pulse sterilization of Escherichia coli. J. Electrost. 2002, 55, 227-235. [CrossRef]

112. Ohshima, T.; Tanino, T.; Kameda, T.; Harashima, H. Engineering of operation condition in milk pasteurization with PEF treatment. Food Control 2016, 68, 297-302. [CrossRef]

113. Hülsheger, H.; Potel, J.; Niemann, E.-G. Killing of bacteria with electric pulses of high field strength. Radiat. Environ. Biophys. 1981, 20, 53-65. [CrossRef]

114. Montanari, C.; Tylewicz, U.; Tabanelli, G.; Berardinelli, A.; Rocculi, P.; Ragni, L.; Gardini, F. Heat-assisted pulsed electric field treatment for the inactivation of Saccharomyces cerevisiae: Effects of the presence of citral. Front. Microbiol. 2019, 10, 1737. [CrossRef] [PubMed] 